NBER WORKING PAPER SERIES

\title{
THE ELUSIVE WELFARE ECONOMICS OF PRICE STABILITY AS A MONETARY POLICY OBJECTIVE: SHOULD NEW KEYNESIAN CENTRAL BANKERS PURSUE PRICE STABILITY?
}

\author{
Willem H. Buiter \\ Working Paper 10848 \\ http://www.nber.org/papers/w10848
NATIONAL BUREAU OF ECONOMIC RESEARCH
1050 Massachusetts Avenue
Cambridge, MA 02138
October 2004

The views and opinions expressed are those of the author. They do not necessarily represent the views and opinions of the European Bank for Reconstruction and Development. I would like to thank Anne Sibert for many helpful discussions on the issues discussed in this paper. Seminar participants at Nuffield College made many useful comments. The views expressed herein are those of the author(s) and not necessarily those of the National Bureau of Economic Research.

(C2004 by Willem H. Buiter. All rights reserved. Short sections of text, not to exceed two paragraphs, may be quoted without explicit permission provided that full credit, including $\mathbb{C}$ notice, is given to the source. 
The Elusive Welfare Economics of Price Stability as a Monetary Policy Objective: Should New Keynesian Central Bankers Pursue Price Stability?

Willem H. Buiter

NBER Working Paper No. 10848

October 2004

JEL No. E3, E4, E5, E6

\begin{abstract}
$\underline{\text { ABSTRACT }}$
The paper studies the inflation rate associated with optimal monetary policy in a standard suite of DSGE models, when fiscal policy is either unrestricted optimal or restricted but supportive of monetary policy. Full nominal price flexibility, nominal prices set one period in advance and Calvo-style staggered overlapping price contracts with a variety of indexation rules for constrained price setters are considered.

For all price setting models, optimal monetary policy implements the Bailey-Friedman Optimal Quantity of Money (OQM) rule: the pecuniary opportunity cost of holding money is equal to zero.

There is an optimal inflation rate for producer prices in the Calvo model, given by the 'core inflation' process generated by the indexation rule of the constrained price setters. It is constant only if core inflation is constant.

A zero rate of producer price inflation is necessary for optimality in the Calvo model, only if all of the following conditions hold.

(1) There is no money or the nominal interest rate on money can be set freely.

(2) The constrained price setters of the Calvo model implement an ill-posed, arbitrary price indexation rule, such as the lagged partial indexation rule used by Woodford to make a case for price stability.

(3) The authorities use neither their tax instruments nor the nominal interest rate to validate the core inflation process.

These results are global - they do not depend on linear approximations at a deterministic, zero-inflation steady state.

Willem H. Buiter

Office of the Chief Economist

European Bank for Reconstruction and Development

One Exchange Square,London EC2A 2EH

UNITED KINGDOM

and NBER

buiterw@ebrd.com
\end{abstract}




\section{Introduction}

The pursuit of an inflation target as the overriding priority of monetary policy has become, alongside central bank operational independence, the defining attribute of a modern monetary authority under a floating exchange rate regime (see e.g. Mishkin [36], King [32], Svensson [38], and Svensson and Woodford [39] and the other papers contained in the volume edited by Bernanke and Woodford [3]). The Reserve Bank of New Zealand led the way in 1989 and 1990. ${ }^{1}$ The UK and Japan were early converts. The European Central Bank has an inflation target that dare not speak its name (albeit an asymmetric and rather awkward one). Of the leading central banks only the Fed has not adopted inflation targeting and even there influential voices are arguing that it should do so.

The most common rationale for the adoption of an inflation target is that this represents an operationally simple and transparent way to pursue price stability. Given the (mainly upward) biases in the real-world price indices used to define the inflation target, a low positive target rate of inflation provides an imperfect observable proxy for a zero rate of inflation of the unobservable true price index or ideal cost of living index.

Abstracting from measurement errors, what are the welfare economic arguments for price stability (defined as a zero rate of inflation going forward) as an objective, or even the overriding objective, of monetary policy? In a recent influential contribution to this topic, Woodford [41] has made a case based on the optimisation of a utilitarian social welfare function in an economy with sluggish price adjustment. A central result of this paper is the demonstration that Woodford's argument for targeting zero inflation is not robust in the very class of New Keynesian dynamic stochastic general equilibrium models considered by him. For it to be valid it must be the case that private price setters never learn, even when they should, and that the policy authorities never act, even though they

\footnotetext{
${ }^{1}$ The exact dating of the adoption of inflation targeting by the New Zealand authorities is difficult. According to the Assistant Governor of the Reserve Bank of New Zealand (Archer [1], footnote 3): "By mid 1989 announced policy included a specific target for inflation and a specific date for that target to be achieved, a target that the Reserve Bank was following. But it was not until early 1990 that the full formal paraphernalia of inflation targeting New Zealand style was in place."
} 
could.

The paper studies optimal monetary policy and the inflation rate associated with optimal monetary policy in a popular, standard 'suite' of dynamic stochastic general equilibrium models. Optimal policy is derived from the optimisation of a utilitarian social welfare function by a benevolent government capable of credible commitment. Consumption, labour supply, production of market goods, price setting, portfolio choice and money demand are derived from the optimising choices of a (quasi-) representative infinite-lived household-producer in an endowment economy. ${ }^{2}$ For simplicity, there is assumed to be a sufficiently rich set of financial markets to permit efficient risk-trading and, in equilibrium, complete risk sharing. There is Dixit-Stiglitz [21] monopolistically competitive price setting by producers of differentiated commodities. The paper considers full nominal price flexibility, nominal prices set one period in advance and Calvo-style staggered overlapping price contracts with a number of price indexation rules for the constrained price setters (see [15]).

Monetary policy means the authorities choosing either sequences of or rules for the risk-free short (one-period) nominal interest rates on money and on non-monetary financial instruments (bonds). 'Authorities' means the consolidated monetary and fiscal authorities.

There are a few relatively minor differences between the model of this paper and the 'industry standard' found e.g. in Woodford [41], as well as two key differences. As regards the former, the demand for money reflects both the 'credit goods - cash goods' variant of the cash-in-advance model and the Allais-Baumol-Tobin shoe-leather costs approach. Leisure does double duty as non-market good and credit good. It follows that there are two monetary distortions when the pecuniary opportunity cost of holding money is positive: shoe-leather costs are excessive and the relative price of cash goods to credit goods is too high. This emphasis on the role of money and the potential presence of

\footnotetext{
${ }^{2}$ Quasi-representative, because individual endowments may differ and the tax rates faced by individual household-producers may differ.
} 
multiple monetary distortions is intended as an antidote to recent theoretical work that over-anticipates possible future technological and institutional developments leading to a cashless society, that is, a world without a unique, distinct, government-issued means of payment and medium of exchange (see e.g. Friedman [26], Freedman [25], Costa and deGrauwe [19], Goodhart [30], Hall [31] and Woodford [41]). In a cashless economy, monetary economics becomes pure numérairology: of the store of value, medium of exchange/means of payment and unit of account triad, only the last role of the monetary unit remains. This paper's maintained hypothesis is that the means-of-payment/medium of exchange role of money still matters, although the cashless economy is considered as a special case.

The main differences between the existing literature and the model of this paper are, first, the attention paid to the price indexation rule adopted by constrained price setters in the Calvo-style price setting model and, second, the careful modelling of the 'non-Keynesian' effects of fiscal policy. Because the authorities are assumed to have unrestricted access to lump-sum taxes, there is Ricardian equivalence: holding constant the sequence of real public spending on goods and services, the growth rate of the nominal money stock and all non-lump-sum taxes, the timing of lump-sum taxation has no implications for either nominal or real equilibrium values. Real public spending is assumed to be exogenous.

The interesting fiscal instruments in this model are the non-lump-sum taxes and subsidies. Woodford [41] introduces a production tax/subsidy in his model to eliminate the excess burden of monopoly power. In the present paper, there are both commodityspecific proportional production taxes/subsidies and a uniform consumption tax or final sales tax. One immediate consequence of introducing a consumption tax is the need to distinguish between the market prices faced by consumers (and the associated aggregate consumer price index), which include the consumption tax, and the prices set by producers (and the associated aggregate producer price index or factor cost price index), which exclude the consumption tax. Calvo-style nominal rigidities are associated with the 
prices set by producers. The consumption tax (the only indirect tax in our model), drives a wedge between consumer prices and producer prices. In conjunction with commodityspecific production taxes (the distortionary direct taxes in our model) they can either, if the authorities are highly informed and flexible, completely undo the inefficiencies introduced by any Calvo price setting scheme and indexation rule, or, if the authorities are restricted to simple feedback rules for their taxes, eliminate enough of these inefficiencies to ensure that the real equilibrium (relative prices, real output, real consumption, real interest rates) becomes invariant under alternative inflation rates of the consumer and producer price indices.

A key finding is that for all price setting models considered, optimal monetary policy implements the Bailey-Friedman Optimal Quantity of Money (OQM) rule: the pecuniary opportunity cost of holding money is set equal to zero (see Bailey [2] and Friedman [27]). If the nominal interest rate on money can be set freely, the OQM rule does not pin down the risk-free nominal interest rate on bonds. The rate of inflation of consumer prices (and for constant indirect taxes) also for consumer prices, will vary one-for-one with the common value assigned to the two risk-free nominal interest rates, but that common value itself can be anything. If the nominal interest rate on money is constrained to equal zero, the optimum rate of consumer price inflation is that associated with a zero risk-free nominal interest rate on bonds. In the familiar special case of a non-stochastic steady state, the rate of consumer price inflation will then be equal to minus the pure rate of time preference.

The rate of producer price inflation depends, given the rate of consumer price inflation, on the behaviour over time of the consumption tax rate. If the nominal interest rate money is zero and a zero nominal interest rate on bonds is required to support the OQM equilibrium, the consumption tax rate can (and with an optimising or merely sensible government will) be dedicated to neutralising the effects on the real economy (including relative prices, cross-sectionally and over time) of any distortionary price indexation rule that may be adopted by the constrained price setters in the Calvo model. If the nominal 
interest rate on money can be set freely, the nominal interest rate on bonds can be used to pursue and achieve the optimal rate of inflation of consumer and producer prices, even with a constant indirect tax rate.

In the Calvo model, optimal policy requires that the actual inflation rate of producer prices be equal to the core rate of producer price inflation generated by the indexation rule of the constrained price setters. The actual and core inflation rates will always coincide if the indexation rule is rational and based on complete current information - full indexation to the current period's actual aggregate producer price level. The real equilibrium (and welfare) will be independent of the rate of producer price inflation in this case. With rational indexation based on partial current information, constrained price setters implement full indexation to the rational expectation of the current period's actual producer price level. In this case the real equilibrium and welfare will be independent of the expected rate of producer price inflation.

Even if the constrained price setters' indexation rule is arbitrary, as in Calvo's original model, which has constrained price setters keeping their nominal prices constant (zero indexation), or in Woodford's model of partial, one-period-lagged indexation to the general producer price level, the same real equilibrium achieved under full current indexation can be achieved. What is required is that either interest rate policy or indirect tax policy validate the core inflation rate of producer prices generated by the indexation rule as the actual inflation rate of producer prices. If the nominal interest rate on money can be chosen freely, the validation of the core inflation rate can be achieved with a constant indirect tax rate, by using the nominal interest rate on bonds as the instrument. If the nominal interest rate on money is zero, the optimal inflation policy can be achieved with a zero interest rate on bonds through the use of the indirect tax rate. Taking the 'microeconomic', relative price effects of production taxes and the consumption tax seriously and endowing the authorities with sufficient information, flexibility and sense to use these fiscal instruments effectively, therefore leads to conclusions that are radically different from those obtained by Woodford (see Woodford [41], especially Chapter 6). 
Outside the cashless economy, zero inflation for the consumer price index never characterises optimal monetary policy when the nominal interest on money is constrained to be zero. Zero inflation for the producer price index only occurs as a fluke. This holds also for the Calvo model with the arbitrary indexation rule for which Woodford establishes that a zero rate of inflation is optimal - partial, lagged price indexation. The optimal rate of producer price inflation in the Calvo model equals the core inflation rate - whatever that happens to be. Woodford's partial lagged price indexation rule has zero producer price inflation as the only constant optimal rate of producer price inflation. Because he considers only a $(\log )$ linear approximation of the model at a zero inflation non-stochastic steady state, he misses the non-constant optimal producer price inflation process supported by his indexation rule.

For a zero rate of consumer price inflation to be the only possible inflation rate under optimal monetary policy, each of the following conditions would have to hold:

(1) Either there is no money or the nominal interest rate on money can be set freely to implement the OQM rule. This is practically unlikely unless the authorities can be convinced to implement Gesell's proposal for a carry tax on currency (see Gesell [28], Goodfriend [29] and Buiter and Panigirtzoglou [12], [13]) or Eisner's proposal for the introduction of a virtual currency (see Eisler [23], Einaudi [22], Davies [20] and Buiter $[8])$.

(2) The constrained price setters of the Calvo model implement an arbitrary price indexation rule that supports only a zero producer price inflation rate in a non-stochastic steady state. An example is Woodford's partial, one-period lagged indexation rule.

(3) The authorities only target a constant rate of inflation. They do not use either the short risk-free nominal interest rate on bonds (if the nominal interest rate on money can be chosen freely) or their non-lump sum direct and indirect tax instruments (if the nominal interest rate on money is constrained to equal zero) to implement policies that make the real equilibrium inflation-neutral and the OQM rule optimal.

If the first condition holds and the authorities use their tax instruments and the nom- 
inal interest rate on bonds optimally, a zero rate of consumer price inflation is consistent with optimal monetary policy, but so is any other rate of consumer price inflation, for any indexation rule, including Woodford's.

Unlike Woodford's analysis, this paper does not base the evaluation of the merits of alternative inflation targets in a non-linear stochastic dynamic model with Calvo price setting, on a log-linear approximation to that model at a deterministic steady state with a zero rate of inflation. The results of this paper are global and the optimal inflation rate of producer prices is not required to be constant.

For the suite of models considered in the paper, there are no robust welfare economic foundations for price stability as an objective of monetary policy.

\section{A formal model of the benchmark economy}

\subsection{The Private Sector}

There is a continuum of households on the unit interval. Each household acts as a consumer, shopper, portfolio investor, money manager, worker-producer-supplier and price setter. ${ }^{3}$ Depending on the activity under consideration, the household in what follows can be referred to as 'producer', 'consumer', 'shopper' or 'price setter'. Household $j$, $j \in[0,1]$ maximizes at $t=0,1,2, \ldots$ the utility function given in $(1) .{ }^{4}$ The expectation operator conditional on information available at time $t$ is $E_{t}$. I assume that the information available to each agent is the same and can be summarised each period by a vector of state variables $\sigma_{t}$. The period sub-utility function for market consumption goods, $u$, is increasing, strictly concave, twice continuously differentiable and satisfies the Inada conditions. The period sub-utility function for leisure, $v$, is non-decreasing and concave

\footnotetext{
${ }^{3}$ This 'yeoman farmer' approach in which households produce and supply goods directly, and in which only the potential labour time of household-producer $j$ can be used in the production of consumption good variety $j$, can easily be extended to include separate households and firms and homogeneous or heterogeneous labour markets.

${ }^{4}$ When Calvo-type price contracts are considered, we should re-interpret the model as one in which there is a continuum of differentiated household-supplier types indexed by $j, j \in[0,1]$ and a continuum of identical household-suppliers of each type indexed by $l^{j}, l^{j} \in[0,1]$.
} 
in $\ell$, and twice continuously differentiable. It satisfies an Inada condition.

$$
\begin{gathered}
E_{t} U_{t}^{j} \equiv u\left(C_{t}^{j}\right)+v\left(\ell_{t}^{j}\right)+\sum_{k=t+1}^{\infty} \beta^{k-t} E_{t}\left[u\left(C_{k}^{j}\right)+v\left(\ell_{k}^{j}\right)\right] \\
1>\beta>0 ; C^{j}, \ell^{j} \geq 0 \\
u^{\prime}>0 ; u^{\prime \prime}<0 ; \lim _{C^{j} \searrow 0} u^{\prime}\left(C^{j}\right)=+\infty ; \lim _{C^{j} \nearrow \infty} u^{\prime}\left(C^{j}\right)=0 ; \\
v^{\prime}>0, v^{\prime \prime} \leq 0 ; \lim _{\ell^{j} \backslash 0} v^{\prime}\left(\ell^{j}\right)=+\infty \\
C^{j}=\left(\int_{0}^{1} c^{j}(i)^{\frac{\eta-1}{\eta}} d i\right)^{\frac{\eta}{\eta-1}}, i \neq j \\
c^{j}(i) \geq 0 ; \eta>1 ;
\end{gathered}
$$

The aggregate consumption index $C^{j}$ is a Dixit-Stiglitz [21] CES composite commodity, defined in (2) with static elasticity of substitution between different varieties $\eta>1$. There is a continuum of different varieties of the consumer goods on the unit interval. Each type of household produces one variety. The amount of variety $i$ consumed by household $j$ in period $t$ is $c_{t}^{j}(i)$. Each period, $t$, every household $j$ is endowed with an amount $e_{t}^{j}>0$ of non-tradable perishable 'potential labour time'. The household can transform the endowment of potential labour time one-for-one either into leisure, $\ell_{t}^{j} \geq 0$, into output of the variety $j$ market consumption good $y^{j} \geq 0$, or into 'shoe-leather' inputs into cash management, $s_{t}^{j} \geq 0$, as shown in (7). Household $j$ consumes all varieties except the $j^{\text {th }}$ variety it produces itself. ${ }^{5}$ Each household $j$ acts competitively as a consumer, taking consumer prices $\tilde{p}(i), i \in[0,1], i \neq j$ as given, but sets its period- $t$ producer price $p_{t}(j)$ as a monopolistic competitor and conjectures that the private and public demand for its product in period $t$ depends on economy-wide real aggregate demand $Y_{t}$ (defined below in equation (41)) and on the relative price of the consumption good it supplies,

\footnotetext{
${ }^{5}$ As long as the price of variety $j$ is positive, we could, because of the continuum of varieties assumption, let household-producer $j$ consume its own variety as well without changing any results. If the number of varieties and the number of household-producers were finite, this would not be the case.
} 
$\tilde{p}_{t}(j)$, and a consumer goods basket with consumer price index $\tilde{P}_{t}$ given in (4), with constant price elasticity $-\eta$ (see (8)). It takes as given the general level of consumer prices $\tilde{P}_{t}$ and economy-wide real private consumption, $C_{t}$, public consumption, $G_{t}$, and output, $Y_{t}$, of the composite commodity. The conjectured demand function (8) will be the actual equilibrium demand function. The prices paid by consumers in period $t$ include a proportional sales tax at the rate $\zeta_{t}>-1$, the unique indirect tax in the model. In addition there are commodity-specific production taxes (subsidies if negative) at the proportional rate $\theta_{t}(j)>-1$ in period $t$ on good $j$, so producer $j$ receives per unit of output sold: $p_{t}(j)\left[1+\theta_{t}(j)\right]^{-1}$, while the consumer pays :

$$
\tilde{p}_{t}(j)=\left(1+\zeta_{t}\right) p_{t}(j)
$$

The consumer price index $\tilde{P}$ and the producer price index $P$ are defined in (4) and (5), respectively:

$$
\begin{aligned}
& \tilde{P}_{t}=\left(\int_{0}^{1} \tilde{p}_{t}(i)^{1-\eta} d i\right)^{\frac{1}{1-\eta}}, \\
& P_{t}=\left(\int_{0}^{1} p_{t}(i)^{1-\eta} d i\right)^{\frac{1}{1-\eta}} .
\end{aligned}
$$

Since the sales tax rate is the same for all commodities,

$$
\frac{\tilde{p}_{t}(i)}{\tilde{P}_{t}}=\frac{p_{t}(i)}{P_{t}}
$$

The inflation factor of the market price index between periods $t_{0}$ and $t_{1}$, denoted $\tilde{\Pi}_{t_{1}, t_{0}}$ is given by

$$
\tilde{\Pi}_{t_{1}, t_{0}} \equiv \frac{\tilde{P}_{t_{1}}}{\tilde{P}_{t_{0}}}
$$

and the inflation factor of the price index at factor cost or producer price index between 
periods $t_{0}$ and $t_{1}$, denoted $\Pi_{t_{1}, t_{0}}$, is defined by

$$
\Pi_{t_{1}, t_{0}} \equiv \frac{P_{t_{1}}}{P_{t_{0}}}
$$

so

$$
\tilde{\Pi}_{t_{1}, t_{0}}=\Pi_{t_{1}, t_{0}}\left(\frac{1+\zeta_{t_{1}}}{1+\zeta_{t_{0}}}\right)
$$

We also have:

$$
\begin{gathered}
e_{t}^{j} \geq \ell_{t}^{j}+y_{t}^{j}+s_{t}^{j}, \\
\ell_{t}^{j}, y_{t}^{j}, s_{t}^{j} \geq 0
\end{gathered}
$$

and

$$
y_{t}^{i}=\left(\frac{p_{t}(i)}{P_{t}}\right)^{-\eta} Y_{t}=\left(\frac{p_{t}(i)}{P_{t}}\right)^{-\eta}\left(C_{t}+G_{t}\right)
$$

Household $j$ pays direct taxes and indirect taxes. Direct taxes are a lump-sum tax, $T_{t}^{j}$ in nominal terms, and the proportional tax on the production of its market good. The indirect tax is the proportional sales tax on all consumer spending.

The household has access to a complete set of time and state-contingent financial markets. There also is money (cash or currency), an unbacked, irredeemable and inconvertible liability of the government. The quantity held at the end of period $t$ by household $j$ is $M_{t}^{j} \geq 0$. A unit of currency held at the end of period $t$ pays a risk-free amount $1+i_{t+1, t}^{m}$ of currency in period $t+1$. A unit of currency serves as the numéraire in price contracts. Households are subject to a cash-in-advance constraint on their purchases of market goods: a fraction $\alpha_{t}(j), 0 \leq \alpha_{t}(j) \leq 1$, of consumer goods purchased in period $t$ by other households from household $j$ must be paid in cash; the remainder is financed with 'trade credit'. The government is assumed not to be subject to a cashin-advance constraint. Leisure is not traded; it has to be consumed by the owner of the 
endowment of potential leisure time. As regards the cash-in-advance constraint, leisure therefore plays a role equivalent to a credit good. The nominal value of household $j^{\prime} s$ portfolio of all non-monetary financial claims held at the end of period $t$ is $F_{t}^{j}{ }^{6}$

I adopt the Lucas [33], [34] version of the timing of transactions. The unit period, $t$, is partitioned into three distinct sub-periods, each of which contains one trading session. All realisations of random variables during period $t$ are known to the households and the government before they take any period $t$ actions. During the first sub-period, household $j$ trades securities, pays taxes, obtains (extends) trade credit to finance the shares $1-$ $\alpha_{t}(i), \quad i \neq j$ of purchases $\left(1-\alpha_{t}(j)\right.$ of sales) of market goods not financed with cash. Household $j$ brings total nominal financial wealth (monetary and non-monetary) $W_{t}^{j}$ to the first sub-period. During this securities trading session, trades that require cash-inadvance cannot be made. The supplier of goods (the household as producer-supplier) is the active money manager, as it is he who is, for one period, 'locked into' the money he receives from the shoppers of the other families. A fraction $\alpha_{t}(j)$ of the before-tax income from period $t$ sales by household $j, \quad \alpha_{t}(j) \tilde{p}_{t}(j)\left(y_{t}^{j}-g_{t}^{j}\right)$ has to be held in the form of money balances by the worker of household $j$ worker until period $t+1$.

Supplier $j$ can economise on the amount of money he needs to carry over to the next period from the sale of its cash goods by expending real resources $s_{t}^{j}$. The shoe-leather technology possesses the property that for sales in the market of $\tilde{p}_{t}(j) y_{t}^{j}$, household $j$ has to accept $\alpha\left(s_{t}^{j}\right) \tilde{p}_{t}(j) y_{t}^{j}$ in cash yielding $1+i_{t+1, t}^{m}$, while $\left[1-\alpha\left(s_{t}^{j}\right)\right] \tilde{p}_{t}(j) y_{t}^{j}$ is paid for with credit instruments yielding $1+i_{t+1, t}$. I assume that $\alpha$ is twice continuously differentiable with $0 \leq \alpha \leq 1 ; \alpha(0)=1 ; \alpha^{\prime} \leq 0 ; \alpha^{\prime \prime} \geq 0$. When $\alpha^{\prime}\left(s_{t}^{j}\right)=0,0 \leq s_{t}^{j} \leq e_{t}^{j}$, then $\alpha \equiv 1$ and we have the pure cash-in-advance model with cash and credit goods (leisure) but without shoe-leather costs. ${ }^{7}$

\footnotetext{
${ }^{6}$ This does not include the one-period risk-free nominally denominated trade credit extended by producers or the one-period risk-free nominally denominated consumption loans taken out by households to finance the shares of their sales or purchases of consumption goods that are not subject to the cashin-advance constraint.

${ }^{7}$ One interpretation of $s_{t}^{j}$ is shopping time (see e.g. Brock [4], and McCallum and Goodfriend [35]), but the interpretation of $s_{t}^{j}$ as representing the real resource cost of active cash management by the producer, that is, shoe-leather costs in the spirit of Allais, Baumol and Tobin seems more apt here.
} 
The government announces its taxes, public spending, money issuance and debt issuance for period $t$ at the beginning of the period, before the securities markets open, and pays interest and principal due on its outstanding stocks of debt instruments. In subperiod one, when the financial markets are open, each household acquires at least the money balances they need to pay for the cash component of period $t$ 's planned purchases of market goods.

Letting $\mu_{t}^{j}$ denote the money balances acquired by household $j$ during the first trading sub-period, the cash-in-advance constraint for household $j^{\prime} s$ shopper is:

$$
\mu_{t}^{j} \geq \int_{0}^{1} \alpha_{t}(i) \tilde{p}_{t}(i) c_{t}^{j}(i) d i .
$$

Household $j$ treats $\alpha_{t}(i), i \in[0,1], i \neq j$ as given. As shown in (9), during the first trading sub-period of period $t$, total financial wealth, $W_{t}^{j}$, is allocated to non-monetary financial claims, $F_{t}^{j}$, money (for use in period $t$ consumption requiring 'cash-in-advance'), $\mu_{t}^{j}$, direct taxes, $T_{t}^{j}+\frac{\theta_{t}(j)}{1+\theta_{t}(j)} p_{t}(j) y_{t}^{j}$, and the financing of the non-cash component of its purchases of market goods, $\int_{0}^{1}\left[1-\alpha_{t}(i)\right] \tilde{p}_{t}(i) c_{t}^{j}(i) d i$, net of the non-cash component of its sales revenue: $-\left[\left[1-\alpha_{t}(j)\right] \tilde{p}_{t}(j)\left(y_{t}^{j}-g_{t}^{j}\right)+\tilde{p}_{t}(j) g_{t}^{j}\right]$, where $g_{t}^{j} \geq 0$ is the amount of good $j$ purchased by the government.

$$
\begin{aligned}
W_{t}^{j} \geq & F_{t}^{j}+\mu_{t}^{j}+T_{t}^{j}+\frac{\theta_{t}(j)}{1+\theta_{t}(j)} p_{t}(j) y_{t}^{j} \\
& +\int_{0}^{1}\left[1-\alpha_{t}(i)\right] \tilde{p}_{t}(i) c_{t}^{j}(i) d i-\left\{\left[1-\alpha_{t}(j)\right] \tilde{p}_{t}(j)\left(y_{t}^{j}-g_{t}^{j}\right)+\tilde{p}_{t}(j) g_{t}^{j}\right\} .
\end{aligned}
$$

In sub-period two, the financial markets are closed. Each household's shopper purchases consumption goods with the money acquired in sub-period one. The government has made its consumption purchases with credit in sub-period one. The supplier in each household $j$ sells $\tilde{p}_{t}(j)\left(y_{t}^{j}-g_{t}^{j}\right)$, the part of its perishable period $t$ endowment that it does not itself consume as leisure or use up as shoe leather costs, to the shoppers of the 
other households or to the government. It sets the factor cost price of good $j$ and chooses its shoe-leather input to maximise the objective function $(1) .{ }^{8}$ It has paid a fraction $\frac{\theta_{t}(j)}{1+\theta_{t}(j)}$ of its period $t$ revenues as production taxes to the government in the first sub-period. A fraction $\alpha_{t}(j)$ of its sales to other households is received in the form of cash balances.

Beginning-of-period total (monetary plus non-monetary) financial wealth in period $t$, $W_{t}^{j}$ consists of the gross returns on the non-monetary financial portfolio purchased in period $t-1, A_{t}^{j}$, plus the gross earnings on the money balances carried over from period $t-1:\left(1+i_{t, t-1}^{m}\right) M_{t-1}^{j}$. The end-of-period $t-1$ stock of money held by household $j, M_{t-1}^{j}$ is the sum of the money received by the household $j$ producer $\alpha_{t}(j) \tilde{p}_{t-1}(j)\left(y_{t-1}^{j}-g_{t-1}^{j}\right)$, plus the 'excess' money balances carried over from period $t-1$ by the household $j$ shopper, $\mu_{t-1}^{j}-\int_{0}^{1} \alpha_{t}(i) \tilde{p}_{t-1}(i) c_{t-1}^{j}(i) d i$. Therefore,

$$
W_{t}^{j} \equiv A_{t}^{j}+\left(1+i_{t, t-1}^{m}\right) M_{t-1}^{j},
$$

where

$$
M_{t-1}^{j}=\alpha_{t-1}(j) \tilde{p}_{t-1}(j)\left(y_{t-1}^{j}-g_{t-1}^{j}\right)+\mu_{t-1}^{j}-\int_{0}^{1} \alpha_{t-1}(i) \tilde{p}_{t-1}(i) c_{t-1}^{j}(i) d i
$$

The set containing all possible values of the state of the economy at time $t, t=$ $0,1,2, \ldots$ is denoted $S$. The state vector is assumed to evolve according to a Markov process with density $f\left(\sigma^{\prime}, \sigma\right)$ defined by.

$$
\operatorname{Prob}\left(\sigma_{t+1} \leq \sigma^{\prime} \mid \sigma_{t}=\sigma\right)=\int_{-\infty}^{\sigma^{\prime}} f(u, \sigma) d u=F\left(\sigma^{\prime}, \sigma\right)
$$

The initial state, $\sigma_{0}$, is assumed given and known to all private agents and the government at time $t=0$. Until further notice, the period- $t$ state vector $\sigma_{t}$ contains the following

\footnotetext{
${ }^{8}$ If the production activities were uncoupled from the 'normal' household activities (consumption, saving and portfolio allocation and labour supply) by having firms as distinct economic entitities owned by the households, the same equilibrium will be supported in a complete markets setting if the firms maximise profits.
} 
elements: (1) all potential sources of exogenous randomness in period $t$ : household endowments, $\left\{e_{t}^{j} ; j \in[0,1].\right\}$, real aggregate public spending $G_{t}$ and all tax rates, $\zeta_{t}$ and $\theta_{t}(j), j \in[0,1] ; \quad(2)$ the value of household stocks of money and non-monetary financial claims carried over from period $t-1,\left\{\left(1+i_{t, t-1}^{m}\right) M_{t-1}^{j} \geq 0, A_{t}^{j} ; j \in[0,1]\right\} ;$ and (3) the period $t$ value of the stock of risk-free one-period nominal bonds issued in period $t-1$ by the government, $\left(1+i_{t, t-1}\right) B_{t-1}$, where $B_{t-1}$ is the nominal stock of one-period risk-free bonds issued by the government in period $t-1$. We denote by $f^{k-t}\left(\sigma_{k}, \sigma_{t}\right)$ the $k-t$ - step-ahead transition function defined from the one-period ahead transition functions $f\left(\sigma^{\prime}, \sigma\right)$ using the recursion:

$$
\begin{aligned}
f^{k-t}\left(\sigma_{k}, \sigma_{t}\right) & =\int_{\sigma_{k} \in S} f\left(\sigma_{k}, \sigma_{k-1}\right) f^{k-t-1}\left(\sigma_{k-1}, \sigma_{t}\right) d \sigma_{k-1}, k>t \\
& =1, k=t .
\end{aligned}
$$

A key requirement of equilibrium is that there be no arbitrage opportunities. There exists a one-period ahead stochastic nominal discount factor or one-step-ahead pricing kernel $I\left(\sigma_{t+1}, \sigma_{t}\right)$, which has the property that, if in period $t$ the economy is in state $\sigma_{t}$, the period- $t$ price in terms of money of 1 unit of period $t+1$ money contingent on the event that $\sigma_{t+1}$ belongs to the set $\Omega \subseteq S$ in period $t+1$, is given by:

$$
E_{\sigma_{t+1} \in \Omega} I\left(\sigma_{t+1}, \sigma_{t}\right)=\int_{\sigma_{t+1} \in \Omega} I\left(\sigma_{t+1}, \sigma_{t}\right) f\left(\sigma_{t+1}, \sigma_{t}\right) d \sigma_{t+1}
$$

It follows that the price in period- $t$ currency, if the period- $t$ state is $\sigma_{t}$, of $Z\left(\sigma_{t+1}\right)$ units of period $t+1$ money contingent on $\sigma_{t+1}$ belonging to the set $\Omega$ in period $t+1$, is

$$
E_{\sigma_{t+1} \in \Omega}\left[Z\left(\sigma_{t+1}\right) I\left(\sigma_{t+1}, \sigma_{t}\right)\right]=\int_{\sigma_{t+1} \in \Omega} Z\left(\sigma_{t+1}\right) I\left(\sigma_{t+1}, \sigma_{t}\right) f\left(\sigma_{t+1}, \sigma_{t}\right) d \sigma_{t+1} .
$$

In particular, the price in period- $t$ currency, if the period- $t$ state is $\sigma_{t}$, of $\tilde{P}_{t+1}\left(\sigma_{t+1}\right)$ units of money contingent on $\sigma_{t+1}$ belonging to the set $\Omega$ in period $t+1$, that is, the price 
in period- $t$ currency, if the period- $t$ state is $\sigma_{t}$, of a unit of the composite consumption good in period $t+1$ if the period $t+1$ state is $\sigma_{t+1}$, is $\tilde{P}_{t+1} I\left(\sigma_{t+1}, \sigma_{t}\right)$. We can then define the single-period stochastic real discount factor

$$
\tilde{R}\left(\sigma_{t+1}, \sigma_{t}\right) \equiv \tilde{\Pi}_{t+1, t} I\left(\sigma_{t+1}, \sigma_{t}\right)
$$

In what follows, for any random variable $X_{t+1}$ the notation $E_{t} X_{t+1}$ is used to define the expectation conditional on the entire state space, $S$, that is,

$$
E_{t} X_{t+1} \equiv \int_{\sigma_{t+1} \in S} X\left(\sigma_{t+1}\right) f\left(\sigma_{t+1}, \sigma_{t}\right) d \sigma_{t+1} . \text { Also, } I_{t+1, t} \equiv I\left(\sigma_{t+1}, \sigma_{t}\right) \text { and } \tilde{R}_{t+1, t} \equiv
$$
$\tilde{R}\left(\sigma_{t+1}, \sigma_{t}\right)$. Multi-period stochastic nominal discount factors can be obtained recursively from the single period stochastic nominal discount factors as follows:

$$
\begin{array}{rlrl}
I_{t_{1}, t_{0}} & \equiv \prod_{k=t_{0}+1}^{t_{1}} I_{k, k-1} ; & t_{1}>t_{0} \\
& \equiv 1 & & t_{1}=t_{0} .
\end{array}
$$

Equation (13) and the law of iterated projections imply that (as long as the information set conditioning expectations at time $t^{\prime} \geq t$ contains the information set conditioning expectations at the earlier time $t$ )

$$
E_{t_{0}}\left[I\left(t_{1}, t_{0}\right) E_{t_{1}} I\left(t_{2}, t_{1}\right)\right]=E_{t_{0}} I\left(t_{2}, t_{0}\right), t_{2} \geq t_{1} \geq t_{0}
$$

Multi-period stochastic real discount factors can be obtained recursively from the single period stochastic real discount factors as follows:

$$
\begin{array}{rlrl}
\tilde{R}_{t_{1}, t_{0}} & \equiv \prod_{k=t_{0}+1}^{t_{1}} \tilde{R}_{k, k-1} ; & t_{1}>t_{0} \\
& \equiv 1 & & t_{1}=t_{0} .
\end{array}
$$

Therefore: 


$$
E_{t_{0}}\left[\tilde{R}\left(t_{1}, t_{0}\right) E_{t_{1}} \tilde{R}\left(t_{2}, t_{1}\right)\right]=E_{t_{0}} \tilde{R}\left(t_{2}, t_{0}\right), t_{2} \geq t_{1} \geq t_{0}
$$

Let $A_{t+1}^{j}=A^{j}\left(\sigma_{t+1}\right)$ be the net amount purchased by household $j$ at time $t$ of the security paying one unit of money if the economy is in state $\sigma_{t+1}$ at time $t+1$. The value, at time $t$, of the portfolio of non-monetary financial instruments held by household $j, F_{t}^{j}$ is given by:

$$
F_{t}^{j}=\int_{\sigma_{t+1} \in S} I_{t+1, t} A^{j}\left(\sigma_{t+1}\right) f\left(\sigma_{t+1}, \sigma_{t}\right) d \sigma_{t+1}=E_{t}\left(I_{t+1, t} A_{t+1}^{j}\right)
$$

Two specific financial portfolios are of special interest in what follows. The first is a portfolio paying one unit of money in period $t+1$, regardless of which state of the world $\sigma_{t+1}$ is realised (that is, $A^{j}\left(\sigma_{t+1}\right)=1$ for all $\left.\sigma_{t+1} \in S\right)$. This defines the one-period risk-free nominal interest rate $i_{t, t+1}$ :

$$
\frac{1}{1+i_{t+1, t}} \equiv \int_{\sigma_{t+1} \in S} I_{t+1, t} f\left(\sigma_{t+1}, \sigma_{t}\right) d \sigma_{t+1}=E_{t} I_{t+1, t}
$$

The second is a portfolio paying one unit of the composite consumption good in period $t+1$, that is, $A^{j}\left(\sigma_{t+1}\right)=\tilde{P}_{t+1}\left(\sigma_{t+1}\right)$ units of money, in every state of the world $\sigma_{t+1}$. This defines the one-period risk-free real interest rate on non-monetary financial instruments, $\tilde{r}_{t, t+1}:$

$$
\begin{aligned}
\frac{1}{1+\tilde{r}_{t+1, t}} & \equiv \tilde{P}_{t}^{-1} \int_{\sigma_{t+1} \in S} I_{t+1, t} \tilde{P}_{t+1} f\left(\sigma_{t+1}, \sigma_{t}\right) d \sigma_{t+1} \\
& =\tilde{P}_{t}^{-1} E_{t}\left(I_{t+1, t} \tilde{P}_{t+1}\right)=E_{t}\left(I_{t+1, t} \tilde{\Pi}_{t+1, t}\right) .
\end{aligned}
$$

If (9) holds with equality (as it will when the household chooses an optimal pro- 
gramme), (9) and (10) can be combined to yield:

$$
\begin{gathered}
E_{t}\left(I_{t+1, t} W_{t+1}^{j}\right) \equiv W_{t}^{j}+p_{t}(j)\left[1+\theta_{t}(j)\right]^{-1} y_{t}^{j}-T_{t}^{j}-\int_{0}^{1} \tilde{p}_{t}(i) c_{t}^{j}(i) d i \\
+E_{t}\left[I_{t+1, t}\left(1+i_{t+1, t}^{m}\right)-1\right]\left(\alpha_{t}(j) \tilde{p}_{t}(j)\left(y_{t}^{j}-g_{t}^{j}\right)+\mu_{t}^{j}-\int_{0}^{1} \alpha_{t}(i) \tilde{p}_{t}(i) c_{t}^{j}(i) d i\right) .
\end{gathered}
$$

Because of (18) and the assumption that the interest rate on money is risk-free, (20) can be written as:

$$
\begin{aligned}
E_{t}\left(I_{t+1, t} W_{t+1}^{j}\right) \equiv & W_{t}^{j}+p_{t}(j)\left[1+\theta_{t}(j)\right]^{-1} y_{t}^{j}-T_{t}^{j}-\int_{0}^{1} \tilde{p}_{t}(i) c_{t}^{j}(i) d i \\
& -\lambda_{t+1, t}\left(\alpha_{t}(j) \tilde{p}_{t}(j)\left(y_{t}^{j}-g_{t}^{j}\right)+\mu_{t}^{j}-\int_{0}^{1} \alpha_{t}(i) \tilde{p}_{t}(i) c_{t}^{j}(i) d i\right) .
\end{aligned}
$$

where

$$
\lambda_{t+1, t} \equiv\left(\frac{i_{t+1, t}-i_{t+1, t}^{m}}{1+i_{t+1, t}}\right)
$$

The household solvency constraint is the no-Ponzi requirement that the expected present discounted value of its terminal net financial wealth be non-negative, that is

$$
\lim _{k \rightarrow \infty} E_{t} I_{k, t} W_{k}^{j} \geq 0
$$

Equations (21), (12), (14) and (22) imply the period $t$ intertemporal budget constraint of household $j$ :

$$
\frac{W_{t}^{j}}{\tilde{P}_{t}} \geq E_{t} \sum_{k=t}^{\infty} \tilde{R}_{k, t}\left(\begin{array}{c}
\int_{0}^{1} \frac{p_{k}(i)}{P_{k}} c_{k}^{j}(i) d i+\frac{T_{k}^{j}}{\tilde{P}_{k}}-\frac{p_{k}(j)}{P_{k}} \frac{1}{\left(1+\zeta_{k}\right)\left[1+\theta_{k}(j)\right]} y_{k}^{j} \\
+\lambda_{k+1, k}\left(\alpha_{k}(j) \frac{p_{k}(j)}{P_{k}}\left(y_{k}^{j}-g_{k}^{j}\right)+\frac{\mu_{k}^{j}}{\tilde{P}_{k}}-\int_{0}^{1} \alpha_{k}(i) \frac{p_{k}(i)}{P_{k}} c_{k}^{j}(i) d i\right)
\end{array}\right)
$$

I assume that $i_{t, t+1} \geq i_{t, t+1}^{m}$ for all $t$. If not, the simplest possible arbitrage argument would show that infinite risk-free profits could be made by households borrowing at the 
rate $i_{t, t+1}$ and investing the proceeds in money earning a rate $i_{t, t+1}^{m}$.

In addition to the transactions role attributed to the monetary financial instrument, money is also assumed to be the numéraire. In the flexible price level model the choice of numéraire has no implications for the behaviour of equilibrium real variables. When there are nominal rigidities in price setting, that is, rigidities in terms of the numéraire, the (bold) assumptions that (1) the monetary authorities determine the numéraire and that (2) the monetary authorities can set the interest rate in terms of that numéraire, are of great significance for the real economy. ${ }^{9}$

When prices $p_{t}(j)$ can be set freely by supplier $j$ in period $t$, the optimality conditions for household $j$ 's consumption, leisure, shoe-leather and pricing decisions are as follows for all $t \geq 0$ :

$$
\begin{gathered}
c_{t}^{j}(i)=C_{t}^{j}\left(\frac{p_{t}(i)}{P_{t}}\right)^{-\eta}, i \in[0,1] \\
v^{\prime}\left(\ell_{t}^{j}\right)=u^{\prime}\left(C_{t}^{j}\right) \frac{p_{t}(j)}{P_{t}}\left(\frac{\eta-1}{\eta}\right)\left[\frac{1}{\left(1+\zeta_{t}\right)\left[1+\theta_{t}(j)\right]}-\alpha\left(s_{t}^{j}\right) \lambda_{t+1, t} \frac{C_{t}}{Y_{t}}\right] \\
v^{\prime}\left(\ell_{t}^{j}\right)=-\alpha^{\prime}\left(s_{t}^{j}\right) u^{\prime}\left(C_{t}^{j}\right) \frac{p_{t}(j)}{P_{t}}\left(y_{t}^{j}-g_{t}^{j}\right) \text { if } \alpha^{\prime}<0 \text { and } i_{t+1, t}>i_{t+1, t}^{m} \\
s_{t}^{j}=0, \alpha=1 \text { if } \alpha^{\prime}\left(s_{t}^{j}\right)=0,0 \leq s_{t}^{j} \leq e_{t}^{j} \text { or if } i_{t+1, t}=i_{t+1, t}^{m} \\
e_{t}^{j}=\ell_{t}^{j}+s_{t}^{j}+y_{t}^{j}
\end{gathered}
$$

\footnotetext{
${ }^{9}$ The more common set of assumptions is that (1) the numéraire for price and wage contracts happens to be the unit of the unique financial instrument that fulfills the means of payment/medium of exchange function (money) and (2) the state has the monopoly of the issuance of money and can fix the risk-free interest rate in terms of money. The assumptions in the main text create a role for 'monetary policy' or rather, nominal interest rate policy, also in an economy without a distinct monetary financial instrument - a 'cashless' economy, (see Woodford [41]).
} 


$$
u^{\prime}\left(C_{t+1}^{j}\right)=\beta^{-1} I_{t+1, t} \tilde{\Pi}_{t+1, t} u^{\prime}\left(C_{t}^{j}\right) \text { for each state } \sigma_{t+1} .
$$

$$
\begin{aligned}
\mu_{t}^{j} & \geq \int_{0}^{1} \alpha\left(s_{t}^{i}\right) \tilde{p}_{t}(i) c_{t}^{j}(i) d i \\
& =\int_{0}^{1} \alpha\left(s_{t}^{i}\right) \tilde{p}_{t}(i) c_{t}^{j}(i) d i \text { if } i_{t+1, t}>i_{t+1, t}^{m}
\end{aligned}
$$

The household solvency constraint and the Standard Transversality Condition imply that $(22)$ holds with equality: ${ }^{10}$

$$
\lim _{k \rightarrow \infty} E_{t} I_{k, t} W_{k}^{j}=0
$$

The Euler equation (28) has to hold for all $t \geq 0$ and for all possible states at each date. From the one-period risk-free nominal interest rate definition (18) it then follows that :

$$
1+i_{t+1, t}=\frac{\beta^{-1} u^{\prime}\left(C_{t}^{j}\right)}{E_{t}\left(u^{\prime}\left(C_{t+1}^{j}\right) \tilde{\Pi}_{t, t+1}\right)}
$$

Likewise, from the definition of the one-period risk-free real interest rate (19), it then follows that:

$$
1+\tilde{r}_{t+1, t}=\frac{\beta^{-1} U^{\prime}\left(C_{t}^{j}\right)}{E_{t} u^{\prime}\left(C_{t+1}^{j}\right)}
$$

\subsection{The public sector}

In period $t$, the government spends $\tilde{P}_{t} G_{t}$ on consumption goods, levies lump-sum taxes $T_{t}=\int_{0}^{1} T_{t}^{j} d j$, production taxes $\int_{0}^{1} \frac{\theta_{t}(j)}{1+\theta_{t}(j)} p_{j}(t) y_{t}^{j} d j$ and sales tax $\zeta_{t} P_{t} Y_{t}$ and finances any

\footnotetext{
${ }^{10}$ The Standard Transversality Condition for the consumer's optimisation problem is $u^{\prime}\left(C_{t}^{j}\right) \frac{\lim _{k \rightarrow \infty} E_{t} I_{k, t} W_{k}^{j}}{\tilde{P}_{t}}=0$.
} 
budget deficit by issuing money or one-period maturity risk-free nominal bonds. The aggregate stocks of money and nominal bonds outstanding at the end of period $t$ are $M_{t}$ and $B_{t}$ respectively. The government period budget constraint is:

$$
M_{t}+B_{t} \equiv\left(1+i_{t, t-1}^{m}\right) M_{t}+\left(1+i_{t, t-1}\right) B_{t-1}+\tilde{P}_{t} G_{t}-T_{t}-\int_{0}^{1} \frac{\theta_{t}(j)}{1+\theta_{t}(j)} p_{t}(j) y_{t}^{j} d j-\zeta_{t} P_{t} Y_{t}
$$

Real aggregate public spending in terms of the composite commodity, $G_{t}$, is distributed across the individual public consumption goods, $g_{t}(i), i \in[0,1]$ in the same manner as private consumption, that is,

$$
\begin{gathered}
g_{t}^{j}=G_{t}\left(\frac{p_{t}(j)}{P_{t}}\right)^{-\eta} \\
G=\left(\int_{0}^{1}\left(g^{i}\right)^{\frac{\eta-1}{\eta}} d i\right)^{\frac{\eta}{\eta-1}} . \\
e^{i}>g^{i} \geq 0
\end{gathered}
$$

The government's solvency constraint requires the present discounted value of its terminal non-monetary debt to be non-positive, that is,

$$
\lim _{k \rightarrow \infty} E_{t} I_{k, t}\left(1+i_{k, k-1}\right) B_{k-1} \leq 0 .
$$

Equations (33) and (34)imply the government's intertemporal budget constraint:

$$
\begin{gathered}
\left(1+i_{t, t-1}\right) B_{t-1} \leq \\
E_{t} \sum_{k=t}^{\infty} I_{k, t}\left(T_{k}+\int_{0}^{1} p_{k}(j)\left(\frac{\theta_{k}(j)}{1+\theta_{k}(j)}\right) y_{k}^{j} d j+\zeta_{k} P_{k} Y_{k}-\tilde{P}_{k} G_{k}+M_{k}-\left(1+i_{k, k-1}^{m}\right) M_{k-1}\right) .
\end{gathered}
$$

Aggregate real government spending $G$ is exogenous and aggregate lump-sum taxes 
adjust endogenously to keep constant the real value of the stock of non-monetary public debt at its initial value $\tilde{b}_{0}$, that is,

$$
\tilde{\tau}_{t}=\tilde{r}_{t+1, t} \tilde{b}_{0}+G_{t}-\int_{0}^{1}\left(\frac{\theta_{t}(j)}{1+\theta_{t}(j)}\right) \frac{p_{t}(j)}{\left(1+\zeta_{t}\right) P_{t}} y_{t}^{j} d j-\frac{\zeta_{t}}{1+\zeta_{t}} Y_{t}-\tilde{\vartheta}_{t}
$$

where real taxes, $\tilde{\tau}$, real non-monetary debt $\tilde{b}$ and real seigniorage $\tilde{\vartheta}$, are defined, respectively, as $\tilde{\tau}_{t} \equiv T_{t} / \tilde{P}_{t} ; \tilde{b}_{0} \equiv B_{0} / \tilde{P}_{0}$ and $\tilde{\vartheta}_{t} \equiv \frac{M_{t}-\left(1+i_{t, t-1}^{m}\right) M_{t-1}}{\tilde{P}_{t}}$. The fiscal rule (36) only determines aggregate lump-sum taxes. Lump-sum taxes on individuals $T_{t}^{j}, j \in[0,1]$ can be chosen by the policy authorities to achieve any distributional objectives they may have, subject only to the constraint that $\int_{0}^{1} T_{t}^{j} d j=\tilde{P}_{t} \tilde{\tau}_{t}$.

The optimal determination of the production tax rates $\theta_{t}(j)$, the sales tax rate $\zeta_{t}$ and the two short nominal interest rates $i_{t+1, t}$ and $i_{t+1, t}^{m}$ is deferred till Section 3. All four policy instruments are treated as exogenous here, with $i_{t+1, t} \geq i_{t+1, t}^{m}$. The nominal money stock will be endogenous when $i_{t+1, t}>i_{t+1, t}^{m}$. However, when $i_{t+1, t}=i_{t+1, t}^{m}$, the authorities can determine the path of the nominal money stock. In that case I assume that the nominal money stock grows at a proportional rate less than the nominal interest rate on money. This ensures that the boundary condition implied by the household's 'standard transversality condition' (30) and the government's solvency constraint (35) and fiscal rule (36) can be satisfied when monetary policy implements the OQM rule:

$$
\text { If } i_{t+1, t}=i_{t+1, t}^{m} \text { then } M_{t+1}=(1+\nu) M_{t} ; \nu<i_{t+1, t}^{m}
$$

\subsection{Aggregation and equilibrium}

With identical tastes and complete markets for risk-sharing, differences among individual household behaviour occur for just two reasons: differences in the present value of lifetime resources and different realisations of the random endowment $e_{t}^{j}$. Leisure (a non-market good) is separable in the period utility function from the consumption of market goods. Shoe-leather inputs $s_{t}^{j}$ are likewise 'effectively' separable from the consumption of market 
goods. Therefore, different realisations of $e_{t}^{j}$ will not result in differences among households $j$ in their consumption of individual market goods, $i, c_{t}^{j}(i), i \in[0,1]$ or in aggregate consumption of market goods, $C_{t}^{j}$, provided the present value of net lifetime resources, defined by the left-hand-side of equation (38), is the same for all agents.

$$
W_{t}^{j}+E_{t} \sum_{k=t}^{\infty} I_{k, t}\left[p_{k}(j) \frac{1}{1+\theta_{k}(j)} y_{k}^{j}-T_{k}^{j}-\lambda_{k+1, k} M_{k}^{j}\right]=E_{t} \sum_{k=t}^{\infty} I_{k, t} \tilde{P}_{k} C_{k}^{j}
$$

For aggregate consumption of market goods to be representable as the choice of a representative agent, it suffices to assume that the initial value of the financial endowment plus the present value of lump-sum taxes, $W_{0}^{j}+E_{0} \sum_{k=0}^{\infty} I_{k, 0} T_{k}^{j}$ of each agent is such as to offset any differences in $E_{0} \sum_{k=0}^{\infty} I_{k, 0}\left[p_{k}(j) \frac{1}{1+\theta_{k}(j)} y_{k}^{j}-\lambda_{k+1, k} M_{k}^{j}\right]$. Because of complete risk-sharing and separability in the period utility function between consumption of market goods and consumption of leisure, the left-hand-side of (38) will be the same for all agents in periods $t>0$ if it is the same for $t=0$.

Given these assumptions aggregate consumption of all goods, $C_{t}$ is given by:

$$
\int_{0}^{1} C_{t}^{j} d j=C_{t}=C_{t}^{j}, j \in[0,1]
$$

Aggregate consumption of good $i$ is denoted $c_{t}(i)$, that is,

$$
c_{t}(i) \equiv \int_{0}^{1} c^{j}(i) d j
$$

The consumption of good $i, i \in[0,1]$ is the same for all consumers $j, j \in[0,1]$

$$
c_{t}^{j}(i)=c_{t}(i), j \in[0,1] .
$$

Equilibrium in the market for consumption good $i$ is given by:

$$
c_{t}(i)+g_{t}(i)=y_{t}(i)
$$


Monetary equilibrium is given by:

$$
\int_{0}^{1} M_{t}^{j} d j=M_{t}
$$

Aggregate real GDP is given by:

$$
Y_{t} \equiv\left(\int_{0}^{1}\left(y_{t}^{j}\right)^{\frac{\eta-1}{\eta}} d j\right)^{\frac{\eta}{\eta-1}}
$$

The aggregate demand for consumption good $i$ is given by:

$$
y_{t}^{j}=Y_{t}\left(\frac{p_{t}(j)}{P_{t}}\right)^{-\eta}
$$

which confirms the conjecture of the monopolistic price setter for consumption good $i$ in equation (8).

Equilibrium in the market for non-monetary financial claims is given by:

$$
\int_{0}^{1} F_{t}^{j} d j=B_{t}
$$

Given exogenous $i_{t+1, t}, i_{t+1, t}^{m}, G_{t}, \zeta_{t}$ and $\theta_{t}(j)$, equilibrium is characterised by equations (44) to (54) which hold for all $t \geq 0$ and for $j, i \in[0,1]$ :

$$
\begin{aligned}
\frac{M_{t}}{\tilde{P}_{t}} & \geq C_{t} \int_{0}^{1} \alpha\left(s_{t}^{i}\right) d i \\
& =C_{t} \int_{0}^{1} \alpha\left(s_{t}^{i}\right) d i \text { if } i_{t+1, t}>i_{t+1, t}^{m} \\
v^{\prime}\left(\ell_{t}^{j}\right)=u^{\prime}\left(C_{t}\right) \frac{p_{t}(j)}{P_{t}} & \left(\frac{\eta-1}{\eta}\right)\left[\frac{1}{\left(1+\zeta_{t}\right)\left[1+\theta_{t}(j)\right]}-\alpha\left(s_{t}^{j}\right) \lambda_{t+1, t} \frac{C_{t}}{Y_{t}}\right]
\end{aligned}
$$




$$
\begin{aligned}
v^{\prime}\left(\ell_{t}^{j}\right) & =-u^{\prime}\left(C_{t}\right) \alpha^{\prime}\left(s_{t}^{j}\right) \lambda_{t+1, t} C_{t}\left(\frac{p_{t}(j)}{P_{t}}\right)^{1-\eta} \text { if } \alpha^{\prime}\left(s_{t}^{j}\right)<0 \& i_{t+1, t}>i_{t+1, t}^{m} \\
s_{t}^{j} & =0, \alpha=1 \text { if } \alpha^{\prime}\left(s_{t}^{j}\right)=0,0 \leq s_{t}^{j} \leq e_{t}^{j} \text { or if } i_{t+1, t}=i_{t+1, t}^{m}
\end{aligned}
$$

$$
\begin{gathered}
\lambda_{t+1, t}=\frac{i_{t+1, t}-i_{t+1, t}^{m}}{1+i_{t+1, t}} \\
\ell_{t}^{j}=e_{t}^{j}-s_{t}^{j}-\left(\frac{p_{t}(j)}{P_{t}}\right)^{-\eta} Y_{t} \\
\int_{0}^{1}\left(\frac{p_{t}(j)}{P_{t}}\right)^{1-\eta} d j=1 \\
c_{t}^{j}(i)=\left(\frac{p_{t}(j)}{P_{t}}\right)^{-\eta} C_{t} \\
C_{t}+G_{t}=Y_{t}
\end{gathered}
$$$$
1+i_{t+1, t}=\frac{\beta^{-1} u^{\prime}\left(C_{t}\right)}{E_{t}\left[u^{\prime}\left(C_{t+1}\right) \tilde{\Pi}_{t, t+1}\right]}
$$$$
\tilde{\Pi}_{t+1, t}=\left(\frac{1+\zeta_{t+1}}{1+\zeta_{t}}\right) \Pi_{t+1, t}=\left(\frac{1+\zeta_{t+1}}{1+\zeta_{t}}\right) \frac{P_{t+1}}{P_{t}}
$$

$$
\lim _{k \rightarrow \infty} E_{t} I_{k, t}\left(1+i_{k, k-1}^{m}\right) M_{k-1}=\tilde{P}_{t} \lim _{k \rightarrow \infty} E_{t} \tilde{R}_{k, t}\left(1+i_{k, k-1}^{m}\right) \frac{M_{k-1}}{\tilde{P}_{k-1}}=0
$$

The boundary condition (54) is derived from equation (30) and the financial market equilibrium condition (43). These imply (defining $W_{k} \equiv \int_{0}^{1} W_{k}^{j} d j$ ) that: 


$$
\lim _{k \rightarrow \infty} E_{t} I_{k, t} W_{k}=\lim _{k \rightarrow \infty} E_{t} I_{k, t}\left[\left(1+i_{k, k-1}^{m}\right) M_{k-1}+\left(1+i_{k, k-1}\right) B_{k-1}\right]=0 .
$$

Since $\lim _{k \rightarrow \infty} E_{t} I_{k, t}\left(1+i_{k, k-1}\right) B_{k-1}=\tilde{P}_{t} \lim _{k \rightarrow \infty} E_{t} \tilde{R}_{k-1, t} \tilde{b}_{k-1}=\tilde{P}_{t} \lim _{k \rightarrow \infty} E_{t} \tilde{R}_{k-1, t} \tilde{b}_{0}$ because of the government's tax rule (36), it follows that (54) has to hold in equilibrium whenever the long-run expected real interest rate is positive, that is whenever $\lim _{k \rightarrow \infty} E_{t} \tilde{R}_{k-1, t}=0$.

Consider the behaviour of the economy starting from any period $t=0$. Equations (44), to (53) determine for $t \geq 0$ and for $j, i \in[0,1], M_{t} / \tilde{P}_{t}, Y_{t}, C_{t}, \tilde{\Pi}_{t+1, t}, \Pi_{t+1, t}$, $p_{t}(j) / P_{t}, \ell_{t}^{j}, s_{t}^{j}, c_{t}^{j}(i)$. The boundary condition (54) places restrictions on the long-run behaviour of the real stock of money balances. These restrictions will rule out most deflationary bubble and liquidity trap solutions except those, like the OQM equilibrium, where the nominal money stock goes to zero in the long run (see Buiter [7], [9] and Buiter and Sibert [14]). This motivates the specification of the rule governing the nominal money stock when the opportunity cost of holding money balances is zero in equation (37).

As expected, the model with full price flexibility exhibits nominal indeterminacy: only real output, real consumption, leisure, shoe leather inputs, real interest rates, real money balances $M_{t} / \tilde{P}_{t}$, relative prices $p_{t}(j) / P_{t}$ and the inflation rates $\tilde{\Pi}_{t+1, t}$ and $\Pi_{t+1, t}$ are determinate. The nominal money stock, the general consumer and producer price levels and the nominal values of the prices of the individual goods are indeterminate. With exogenous risk-free nominal interest rates (or with any rules for the two nominal interest rates that depend on real variables only), there is no nominal anchor.

\section{Optimal monetary and tax policy}

We assume that a utilitarian government capable of credible precommitment maximises the sum of the utilities of all households, that is, it chooses $\left\{i_{t+1, t}, i_{t+1, t}^{m}, \theta_{t}(j), \zeta_{t}, T_{t}^{j} ; j \in\right.$ $[0,1], t=0,1,2, \ldots\}$ to maximise (55) subject to the equilibrium conditions of the model, given in equations (44) to (54) and $\int_{0}^{1} T_{t}^{j} d j=\tilde{P}_{t} \tau_{t}$. 


$$
W_{t}=\int_{0}^{1} E_{t} U_{t}^{j} d j \equiv u\left(C_{t}\right)+\int_{0}^{1} v\left[\ell_{t}(j)\right] d j+\sum_{k=t+1}^{\infty} \beta^{k-t} E_{t}\left[u\left(C_{k}\right)+\int_{0}^{1} v\left[\ell_{k}(j)\right] d j\right]
$$

If the government has access to unrestricted lump-sum taxes it needs either the aggregate consumption tax or a uniform production tax to implement a Pareto-efficient equilibrium. By setting the pecuniary opportunity cost of holding money equal to zero, it reduces to zero the real resources used up as shoe-leather costs. It can then use either of the two taxes (or both in combination) to eliminate the distortions that drive a wedge between the private opportunity cost of leisure and its social opportunity cost. The private marginal cost of leisure is below the social marginal cost for two reasons. First, because sales of the consumption good are partly paid for in cash which earns the nominal risk-free interest rate on money, $i_{t+1, t}^{m}$, rather than the nominal risk-free interest rate on bonds, $i_{t+1, t}$, it follows that, if $i_{t+t, t}>i_{t+1, t}^{m}$, the implicit private opportunity cost in terms of leisure foregone of consumption goods produced for the market by household is below the social marginal cost. This 'Austrian' distortion exists even in the pure cash goods and credit goods cash-in-advance model which does not have shoe-leather costs $\left(\alpha^{\prime}\left(s_{t}^{j}\right)=0,0 \leq s_{t}^{j} \leq e_{t}^{j}\right.$, so $\left.s_{t}^{j}=0, \alpha=1\right)$. Second, the household has monopoly power (if $\eta<\infty)$ in the market for the consumption good it produces and sells. The following two propositions can be verified by inspection of the equilibrium conditions (44) to (54):

Proposition 1 In the model with perfect price flexibility and an operative shoe-leather mechanism $\left(\alpha^{\prime}\left(s_{t}^{j}\right)<0\right)$, a Pareto-efficient equilibrium is supported by the following policies:

$$
\begin{gathered}
i_{t+1, t}=i_{t+1, t}^{m}, t \geq 0 \\
\frac{1}{\left(1+\zeta_{t}\right)\left[1+\theta_{t}(j)\right]}=\frac{\eta}{\eta-1}, j \in[0,1], t \geq 0
\end{gathered}
$$

Proposition 2 In the model of Proposition 1, there is 'superneutrality of money' or inflation neutrality: any sequence of consumer and producer price inflation rates can be 
optimal if the nominal interest rate on money can be chosen freely.

The interpretation of the efficiency or social optimality conditions (56) and (57) is straightforward. Equation (56) is the Bailey-Friedman optimal quantity of money (OQM) rule which involves setting the pecuniary opportunity cost of holding real money balances equal to zero. Since $\frac{1}{\left(1+\zeta_{t}\right)\left[1+\theta_{t}(j)\right]}=\frac{\eta}{1-\eta}<1$, equation (57) determines the optimal net effective subsidy to the consumption or production of market goods. Because the price elasticities of demand for the consumption goods are all the same for all goods and constant over time, the optimal subsidy rate is uniform and constant over time.

There is no optimal rate of inflation in the flexible price model or, more precisely, the optimal monetary and fiscal policies (those that support the command optimum), can be achieved with any rate of inflation and any level of the risk-free nominal interest rate on bonds. The OQM rule (56) only requires equality between the short risk-free nominal interest rate on money and the short risk-free nominal interest rate on bonds. A unique equilibrium rate of inflation is determined for any choice of $i_{t+1, t}=i_{t+1, t}^{m}$. Specifically, a unique optimal rate of inflation is defined when $i_{t+1, t}^{m}=0$. This requires $i_{t+1, t}=0$ to support the command optimum, so the inflation rate under the optimal policy is determined by equation (52) with $i_{t+1, t}=0$.

Under the optimal monetary and fiscal policy, the labour market and shoe leather equilibrium conditions become

$$
v^{\prime}\left[e_{t}^{j}-Y_{t}\left(\frac{p_{t}(j)}{P_{t}}\right)^{-\eta}\right]=\frac{p_{t}(j)}{P_{t}} u^{\prime}\left(Y_{t}-G_{t}\right)
$$

and

$$
s_{t}^{j}=0
$$

It is clear that $C_{t+1}=Y_{t+1}-G_{t+1}$ depends only on the exogenous random variables $e_{t+1}^{j}$ and $G_{t+1}$. Its value in any state $\sigma_{t+1}$ is independent of $i_{t+1, t}$. Likewise, $C_{t} \equiv Y_{t}-G_{t}$ depends only on $e_{t}^{j}$ and $G_{t}$. If then follows from (32) that the period $t$ risk-free real interest 
rate, $\tilde{r}_{t+1, t}$ is independent of the period $t$ risk-free nominal interest rate $i_{t+1, t} .>$ From (31) it then follows that the Fisher condition holds:

$$
\frac{d E_{t}\left(\tilde{\Pi}_{t, t+1}\right)}{d\left(1+i_{t+1, t}\right)}=\left(1+\tilde{r}_{t+1, t}\right)^{-1}
$$

In fact, the consumer price inflation rate $\tilde{\Pi}_{t, t+1}$ in every state $\sigma_{t+1}$ satisfies the Fisher condition:

$$
\frac{d\left[\tilde{\Pi}_{t, t+1}\left(\sigma_{t+1}\right)\right]}{d\left(1+i_{t+1, t}\right)}=\left(1+\tilde{r}_{t+1, t}\right)^{-1}, \sigma_{t+1} \in S .
$$

Proposition 3 In the model with perfect price flexibility but without an operative shoeleather mechanism $\left(\alpha^{\prime}\left(s_{t}\right)=0,0 \leq s_{t} \leq e_{t}\right.$, so $\alpha \equiv 1$ and $\left.s_{t}=0\right)$, a Pareto-efficient equilibrium is supported by any values of the policy instruments $\zeta_{t}, \theta_{t}(j), i_{t+1, t}$ and $i_{t+1, t}^{m}$ that satisfy (60) and $i_{t+1, t} \geq i_{t+1, t}^{m}$ :

$$
\frac{1}{\left(1+\zeta_{k}\right)\left[1+\theta_{t}(j)\right]}-\left(\frac{i_{t+1, t}-i_{t+1, t}^{m}}{1+i_{t+1, t}}\right) \frac{C_{t}}{Y_{t}}=\frac{\eta}{\eta-1}
$$

It follows that in the pure 'cash goods and credit goods' cash-in-advance model, the command optimum can be implemented solely through the use of either the sales tax or the production tax (or by the two in combination), with the two short nominal interest rates $i$ and $i^{m}$ set at arbitrary levels, subject only to $i_{t+1, t} \geq i_{t+1, t}^{m}$. The opposite is not true: it is not possible to undo the effect of monopoly simply by using the two nominal interest rates. Since $i \geq i^{m}$, the lowest value of the opportunity cost for money balances is zero. While this eliminates the relative price distortion due to a positive opportunity cost of holding money, even maximal use of the two nominal interest rates cannot overcome the effect of monopoly power. 


\section{Nominal prices set one period in advance}

Assume that nominal prices have to be set one period ahead. Since by assumption the $p_{t}(j)$ cannot be made contingent on the realisation of the state in period $t$, it follows that $E_{t-1} p_{t}(j)=p_{t}(j)$. As this applies to all prices, it also applies to the general producer price level $P_{t}$, whose period- $t$ state-independent value is therefore known in period $t-1$. The first-order conditions for the expected-utility maximising household-producer's period $t$ price, $p_{t}(j)$ is given in equation (61). The first-order condition for the shoe-leather input $s_{t}^{j}$ is the same as in the flexible price model, given in equations (46a) and (46b), because the value of $s_{t}^{j}$ does not have to be set one period in advance. ${ }^{11}$

$$
\begin{aligned}
& E_{t-1} v^{\prime}\left[e_{t}^{j}-s_{t}^{j}-Y_{t}\left(\frac{p_{t}(j)}{P_{t}}\right)^{-\eta}\right] \\
= & \frac{p_{t}(j)}{P_{t}}\left(\frac{\eta-1}{\eta}\right) E_{t-1}\left\{u^{\prime}\left(C_{t}\right)\left[\frac{1}{\left(1+\zeta_{t}\right)\left[1+\theta_{t}(j)\right]}-\alpha\left(s_{t}^{j}\right) \lambda_{t+1, t}\left(\frac{C_{t}}{Y_{t}}\right)\right]\right\}
\end{aligned}
$$

If the government can set unrestricted state-contingent and commodity-specific production taxes $\theta_{t}(j)$, the social optimum of the flexible price level model can still be implemented:

Proposition 4 The same Pareto-efficient equilibrium supported in the flexible price model through the OQM rule (56) and the constant proportional net consumption/production subsidy (57), is supported in the model with nominal prices set one period in advance, by the OQM rule (56) and the state-contingent commodity-specific net consumption/production tax rule implicitly defined by (62):

$$
\frac{E_{t-1}\left(\frac{1}{\left(1+\zeta_{t}\right)\left[1+\theta_{t}(j)\right]} u^{\prime}\left(C_{t}\right)\right)}{u^{\prime}\left(C_{t}\right)}=\left(\frac{\eta}{\eta-1}\right) \frac{E_{t-1}\left[v^{\prime}\left(e_{t}^{j}-Y_{t}\left(\frac{p_{t}(j)}{P_{t}}\right)^{-\eta}\right)\right]}{v^{\prime}\left(e_{t}^{j}-Y_{t}\left(\frac{p_{t}(j)}{P_{t}}\right)^{-\eta}\right)}
$$

\footnotetext{
${ }^{11}$ To save on notation, the equilibrium versions of the household first-order conditions are given equations (61) and (62), that is, I have imposed $C_{t}^{j}=C_{t}$.
} 
The optimal net effective tax rates defined by (62) can also be written as follows:

$$
\frac{1}{\left(1+\zeta_{t}\right)\left[1+\theta_{t}(j)\right]}=\left(\frac{\eta}{\eta-1}\right) \frac{p_{t}^{*}(j)}{p_{t}(j)}
$$

where $p_{t}^{*}(j)$ is the price that would have been set by supplier $j$ in period $t$ if there had been perfect price flexibility. These are the optimal prices under full flexibility determined in Section 3, where each supplier $j$ sets its period $t$ price in period $t$ (or as a function of $\sigma_{t}$ ) rather than in period $t-1$ (or as a function of $\sigma_{t-1}$ ). To achieve the first-best equilibrium, commodity-specific taxes must be used to offset individual endowment shocks. The sales $\operatorname{tax} \zeta_{t}$ is restricted to be uniform across commodities. While it can address the common monopoly power problem, it cannot both do this and neutralise the effect of individual endowment shocks.

When the government applies the OQM rule, every household $j$ setting its price $p_{t}(j)$ in period $t-1$ knows that in period $t$ the government will set $i_{t+1, t}-i_{t+1, t}^{m}=0$. It therefore knows in period $t-1$ that it will not incur any shoe-leather costs in period $t$, that is, it knows that its optimal choice of shoe-leather input in period $t$ will be $s_{t}^{j}=0$.

In period $t-1$ household $j$ sets its price for period $t$ to equate the expected period $t$ marginal utility of leisure, $E_{t-1} v^{\prime}\left[\ell_{t}(j)\right]$, to the expected marginal return to diverting a unit of leisure to market production, $\frac{p_{t}(j)}{P_{t}}\left(\frac{\eta-1}{\eta}\right) E_{t-1}\left\{u^{\prime}\left(C_{t}\right)\left[\frac{1}{\left(1+\zeta_{t}\right)\left[1+\theta_{t}(j)\right]}-\alpha \lambda_{t+1, t} \frac{C_{t}}{Y_{t}}\right]\right\}$. The government eliminates both monetary distortions (shoe-leather cost and the Austrian static relative price distortion) by following the OQM rule. It then can, since it observes the realisation of the state $\sigma_{t}$ in period $t$ before it chooses the production tax rates, $\theta_{t}(j)$, use these taxes to undo both the planned (or expected) monopolistic over-pricing by household $j$ and any unplanned or unexpected mis-pricing due to the random realisations of $e_{t}^{j}, j \in[0,1]$ and $G_{t}$.

Assume instead that the government is no more flexible in its ability to set interest rates and commodity-specific and state-contingent taxes than the private sector is in its ability to set prices. In that case the tax rates $\theta_{t}(j)$ and $\zeta_{t}$, have to be set (and will 
be known to all) in period $t-1$ (or as a function of $\sigma_{t-1}$ ), as do $i_{t+1, t}$ and $i_{t+1, t}^{m}$. The optimality conditions for the household-producer $j$ 's period $t$ price becomes: ${ }^{12}$

$$
\begin{aligned}
& E_{t-1} v^{\prime}\left(\ell_{t}^{j}\right)= \\
& \frac{p_{t}(j)}{P_{t}}\left(\frac{\eta-1}{\eta}\right)\left\{\frac{1}{\left(1+\zeta_{t}\right)\left[1+\theta_{t}(j)\right]} E_{t-1} u^{\prime}\left(C_{t}\right)-\lambda_{t+1, t} E_{t-1}\left[u^{\prime}\left(C_{t}\right) \alpha\left(s_{t}^{j}\right) \frac{C_{t}}{Y_{t}}\right]\right\}
\end{aligned}
$$

It is easily verified that the socially optimal interest rate policy still sets $i_{t+1, t}=$ $i_{t+1, t}^{m}$. With the OQM rule, the authorities minimise shoe-leather costs: $s_{t}^{j}=0$. By assumption, both $i_{t+1, t}$ and $i_{t+1, t}^{m}$ are independent of the state $\sigma_{t}$ because they must be set one period in advance. . As regards the remaining distortion - the ex-post wedge between $\frac{v^{\prime}\left[e_{t}^{j}-s_{t}^{j}-Y_{t}\left(\frac{p_{t}(j)}{P_{t}}\right)^{-\eta}\right]}{u^{\prime}\left(C_{t}\right)} \frac{P_{t}}{p_{t}(j)}$ and 1, that is, $\frac{\eta-1}{\eta}\left(\frac{1}{\left(1+\zeta_{t}\right)\left[1+\theta_{t}(j)\right]}-\alpha\left(s_{t}^{j}\right) \lambda_{t+1, t} \frac{C_{t}}{Y_{t}}\right)$ - there is nothing that can be done by using all four of $\theta_{t}(j), \zeta_{t}, i_{t+1, t}$ and $i_{t+1, t}^{m}$ that cannot be done equally well using just $\frac{1}{\left(1+\zeta_{t}\right)\left[1+\theta_{t}(j)\right]}$ as a single instrument, since all four instruments are, by assumption, constrained to be independent of $\sigma_{t} \cdot{ }^{13}$ In that case, we again have $s_{t}^{j}=0$ and the leisure-market production equilibrium condition becomes:

$$
E_{t-1} v^{\prime}\left[e_{t}^{j}-Y_{t}\left(\frac{p_{t}(j)}{P_{t}}\right)^{-\eta}\right]=\frac{p_{t}(j)}{P_{t}}\left(\frac{\eta-1}{\eta}\right) \frac{1}{\left(1+\zeta_{t}\right)\left[1+\theta_{t}(j)\right]} E_{t-1} u^{\prime}\left(C_{t}\right)
$$

If they have to be set unconditionally one period in advance, the optimal production tax rates cannot ensure the equalisation in each state of the marginal rate of substitution between leisure and consumption of market goods to the 'marginal rate of transformation' between leisure and consumption through production and exchange. Instead this equalisation is achieved 'on average':

\footnotetext{
${ }^{12}$ It makes no difference to the optimal policies if we permit $i_{t+1, t}$ and $i_{t+1, t}^{m}$ to be set in period $t$ rather than in period $t-1$.

${ }^{13}$ For the one-period in advance price setting version of the model, the state $\sigma_{t}$ has to be extended to included the predetermined values of $P_{t}$ and $p_{t}(j), j \in[0,1]$.
} 


$$
E_{t-1} v^{\prime}\left(e_{t}^{j}-Y_{t}\left[p_{t}(j) / P_{t}\right]^{-\eta}\right)=\frac{p_{t}(j)}{P_{t}} E_{t-1} u^{\prime}\left(C_{t}\right), j \in[0,1], t \geq 1
$$

Together with (65), this implies that the net effective tax rate (again, a subsidy) is constant and given by $\frac{1}{\left(1+\zeta_{t}\right)\left[1+\theta_{t}(j)\right]}=\frac{\eta}{\eta-1}$.

Proposition 5 In the model with prices, interest rates and production and consumption tax rates all set one period in advance, the optimal monetary and tax rate policies are the same as in the model with flexible prices, interest rates and production and consumption tax rates. If there is an operative shoe-leather mechanism $\left(\alpha^{\prime}\left(s_{t}^{j}\right)<0\right)$, a (constrained) optimum is achieved by adopting the OQM rule (56) and the constant net effective subsidy rate given in (57).

Corollary 6 In the model with prices, interest rates and production and consumption tax rates all set one period in advance, the optimal monetary and tax policies do not uniquely determine the rate of inflation. Equilibrium inflation varies one-for-one with the level of the short risk-free nominal interest rates, which can be set at any level if the interest rate on money can be set at any level.

\section{Calvo-style staggered overlapping price contracts}

Consider the class of discrete-time Calvo-style overlapping staggered price setting models considered in Woodford [41]. Each period a randomly selected constant fraction $1-\omega, 0<$ $\omega<1$ of all household-suppliers has the opportunity to freely set the nominal price of their product. The optimal price set by the 'free' suppliers in period $t$ is denoted $\hat{p}_{t}(j)$. The remaining share $\omega$ of household-suppliers (the 'constrained' suppliers) sets its price according to a simple indexation rule. ${ }^{14}$

\footnotetext{
${ }^{14}$ It is here that the interpretation, mentioned in footnote 2.1 , of $j$ as indexing household types, $j \in[0,1]$ and there being a continuum of identical household-suppliers indexed by $l^{j}$ of each type $j$, with $l^{j} \in[0,1]$ is helpful in rationalising the expressions for the general price levels in equations (69) and (70) below. A randomly chosen fraction $1-\omega$ of households of each type $j$ is able to set prices freely each period.
} 
The generic indexation rule for the nominal producer price of good $j$ can be written as:

$$
p_{t}(j)=p_{t-1}(j) \Omega_{t, t-1}
$$

or, equivalently,

$$
\frac{p_{t}(j)}{P_{t}}=\frac{p_{t-1}(j)}{P_{t-1}} \Pi_{t-1, t} \Omega_{t, t-1}
$$

I will refer to $\Omega_{t, t-1}$ as core inflation in period $t$. The only restrictions imposed for the moment on $\Omega_{t, t-1}$ are that it is recursive (68a), symmetric (68b), positive (68d), possesses a natural identity transformation (68c) and does not depend on individual characteristics:

$$
\begin{aligned}
\Omega_{t_{2}, t_{1}} \Omega_{t_{1}, t_{0}} & =\Omega_{t_{2}, t_{0}} \\
\Omega_{t_{1}, t_{0}} & =\Omega_{t_{0}, t_{1}}^{-1} \\
\Omega_{t, t} & =1 \\
\Omega_{t_{1}, t_{0}} & >0 .
\end{aligned}
$$

All indexation rule examples below also restrict $\Omega$ to be a function of current and/or past aggregate inflation rates only. The probability that the price of any randomly selected good $j$ will be freely adjustable rather than constrained by the indexing rule in any given period $t$ is also assumed to be equal to $1-\omega$. Because the selection of those who are free to set their period $t$ price is random, the period $t$ price index for the composite consumption good at producer prices or factor cost is given by

$$
P_{t} \equiv\left(\int_{0}^{1} p_{t}(j)^{1-\eta} d j\right)^{\frac{1}{1-\eta}}=\left((1-\omega) \int_{0}^{1} \hat{p}_{t}(j)^{1-\eta} d j+\omega\left(\Omega_{t, t-1} P_{t-1}\right)^{1-\eta}\right)^{\frac{1}{1-\eta}}
$$


The general price level at market prices $\tilde{P}$ is given by: ${ }^{15}$

$$
\tilde{P}_{t} \equiv\left(\int_{0}^{1} \tilde{p}_{t}(j)^{1-\eta} d j\right)^{\frac{1}{1-\eta}}=\left(\int_{0}^{1}\left\{p_{t}(j)\left(1+\zeta_{t}\right)\right\}^{1-\eta} d j\right)^{\frac{1}{1-\eta}}=\left(1+\zeta_{t}\right) P_{t}
$$

From equation (69), I obtain an expression for the producer price inflation factor that motivates referring to $\Omega_{t, t-1}$ as period- $t$ core inflation:

$$
\Pi_{t, t-1}=\left(\frac{\omega}{1-(1-\omega) \int_{0}^{1}\left[\hat{p}(j) / P_{t}\right]^{1-\eta} d j}\right)^{\frac{1}{1-\eta}} \Omega_{t, t-1}
$$

Under the indexation rule (66) the expected value, in period $t$, of the relative price set in period $t+1$ by household $j$ is

$$
E_{t} \frac{p_{t+1}(j)}{P_{t+1}}=\omega \frac{p_{t}(j)}{P_{t}} \Pi_{t, t+1} E_{t} \Omega_{t+1, t}+(1-\omega) E_{t} \frac{\hat{p}_{t+1}(j)}{P_{t+1}}
$$

Therefore, when household-supplier $j$ can freely choose its optimal price in period $t$, that is, when $p_{t}(j)=\hat{p}_{t}(j)$, the expected value of its relative price in period $k>t$ is:

$$
E_{t} \frac{p_{k}(j)}{P_{k}}=\omega^{k-t} \frac{\hat{p}_{t}(j)}{P_{t}} E_{t} \Pi_{t, k} \Omega_{k, t}+(1-\omega) \sum_{n=t+1}^{k} \omega^{k-n} E_{t}\left(\frac{\hat{p}_{n}(j)}{P_{n}} \Pi_{n, k} \Omega_{k, n}\right) .
$$

The optimisation problem for a household that can set its price freely in period $t$ involves choosing $\hat{p}_{t}(j)$ allowing for the effect of this choice on future expected prices, as given by (72). Current and future expected values of the general producer and consumer price levels and the monetary and fiscal policy instruments are taken as given. Using (14) and the consumption Euler equation (52), the relevant first-order condition for the

\footnotetext{
${ }^{15}$ Because markets for risk-trading are complete and because the period utility function is separable in the consumption of market goods and leisure, an appropriate distribution of initial financial wealth (either by chance or through the appropriate use of lump-sum taxes) ensures that all households have the same consumption of market goods: $C_{t}^{j}=C_{t}$, even if different households have different endowment realisations. Different realisations of $e_{t}^{j}$ will, however, be associated with different equilibrium values for $p_{t}(j)$ (and different values of $\ell_{t}^{j}$ ).
} 
choice of $\hat{p}_{t}(j)$ by those household-suppliers $j$ free to set their price optimally in period $t$ is:

$$
\begin{gathered}
\left(\frac{\hat{p}_{t}(j)}{P_{t}}\right)^{-(1+\eta)}\left\{v^{\prime}\left(\ell_{t}^{j}\right)-u^{\prime}\left(C_{t}\right) \frac{\hat{p}_{t}(j)}{P_{t}}\left(\frac{\eta-1}{\eta}\right)\left[\frac{1}{\left(1+\zeta_{t}\right)\left[1+\theta_{t}(j)\right]}-\alpha\left(s_{t}^{j}\right) \lambda_{t+1, t} \frac{C_{t}}{Y_{t}}\right]\right\} \\
+\sum_{k=t+1}^{\infty}(\omega \beta)^{k-t} E_{t}\left(\begin{array}{c}
\frac{Y_{k}}{Y_{t}} \Pi_{t, k} \Omega_{k, t}\left(\frac{p_{k}(j)}{P_{k}}\right)^{-(1+\eta)} \\
\left\{v^{\prime}\left(\ell_{k}^{j}\right)-u^{\prime}\left(C_{k}\right) \frac{p_{k}(j)}{P_{k}}\left(\frac{\eta-1}{\eta}\right)\left[\frac{1}{\left(1+\zeta_{t}\right)\left[1+\theta_{t}(j)\right]}-\alpha\left(s_{k}^{j}\right) \lambda_{k+1, k} \frac{C_{k}}{Y_{k}}\right]\right\}
\end{array}\right)=0 .
\end{gathered}
$$

\subsection{Optimal monetary policy with unrestricted optimal fiscal policy}

If the authorities can freely set state-contingent and commodity-specific production tax rates and state-dependent aggregate consumption tax rates, the first-best, Pareto-efficient equilibrium can be supported - the same command optimum that is supported when prices are fully flexible. The effect of Calvo-style staggered, overlapping price contracts is neutralised by commodity-specific production taxes that equate the price charged by the $j^{\text {th }}$ supplier in period $k, p_{k}(j)$, whenever $p_{k}(j)$ is different from $\hat{p}_{k}(j)$ (because the supplier is locked into a pre-existing contract) to the price he would have charged had he been able to set his price freely in period $k$, that is, $\hat{p}_{k}(j)$. They also correct the monopoly distortion. Either the nominal interest rate on bonds or the consumption tax rate can then be used to ensure that the relative prices faced by consumers are undistorted. Monetary policy implements the OQM rule. By inspection of the equilibrium conditions, including (73), the following proposition can be shown to hold:

Proposition 7 With Calvo-style staggered, overlapping price contracts and for all indexation functions $\Omega_{t, t-1}$, the first-best, Pareto-efficient equilibrium can be supported with 
the OQM rule (56) and fiscal policies satisfying (74) and (75):

$$
\begin{gathered}
\frac{1}{\left(1+\zeta_{t}\right)\left[1+\theta_{t}(j)\right]}=\left(\frac{\eta}{\eta-1}\right) \frac{\hat{p}_{t}(j)}{p_{t}(j)} \\
\frac{1+\zeta_{t-1}}{1+\zeta_{t}} \tilde{\Pi}_{t, t-1} \equiv \Pi_{t, t-1}=\Omega_{t, t-1} .
\end{gathered}
$$

The rate of inflation of consumer prices, $\tilde{\Pi}_{t, t-1}$, is determined from the consumption Euler equation (52). Under the optimal policies, all real variables, including aggregate consumption, are independent of the rates of inflation of consumer and producer prices. The consumption Euler equation therefore determines the rate of consumer price inflation, $\tilde{\Pi}_{t, t-1}$, which moves one-for-one, according to the Fisher condition, with the nominal interest rate $1+i_{t, t-1}$.

For a household-supplier $j$ free to set his price in period $t$, the tax rule (74) implies $\frac{1}{\left(1+\zeta_{t}\right)\left[1+\theta_{t}(j)\right]}=\frac{\eta}{\eta-1}$. For a constrained supplier in period $t$ the tax rule implies $\frac{1}{\left(1+\zeta_{t}\right)\left[1+\theta_{t}(j)\right]}=\left(\frac{\eta}{\eta-1}\right) \frac{\hat{p}_{t}(j)}{P_{t}} \frac{P_{t-1}}{p_{t-1}(j)} \frac{\Pi_{t, t-1}}{\Omega_{t, t-1}}$. For all suppliers $\frac{1}{\left(1+\zeta_{t}\right)\left[1+\theta_{t}(j)\right]} \frac{p_{t}(j)}{P_{t}}=\left(\frac{\eta}{\eta-1}\right) \frac{\hat{p}_{t}(j)}{p_{t}(j)}$ is independent of the rate of producer price inflation.

The full range of commodity-specific production tax rates will in general be needed to implement $(74)$, since $\hat{p}_{t}(j)$ depends on $e_{t}^{j}$. The uniform sales tax is redundant for meeting the production efficiency condition (74). The uniform sales tax is therefore available, together with or instead of the nominal bond interest rate, to eliminate any distortionary effects of the indexation rule (that is, of core inflation) on relative prices faced by consumers. Any indexation rule other than full current indexation to the price level at factor cost $-\Omega_{t, t-1}=\Pi_{t, t-1}$ - distorts the relative prices faced by consumers. It follows that the optimal rate of inflation of producer prices is given by $\Omega_{t, t-1}=\Pi_{t, t-1}$. It is worth stating this as a separate proposition:

Proposition 8 In the Calvo model, the (unconstrained) optimal rate of producer price inflation equals the core rate of producer price inflation: 


$$
\Pi_{t, t-1}=\Omega_{t, t-1}
$$

The optimal rate of producer price inflation can be achieved through two mechanisms. The first is the adoption by constrained price setters of rational indexation (or full, current indexation), that is, $p_{t}(j)=\Pi_{t, t-1} p_{t-1}(j)$ for all constrained price setters $j$. In that case any sequence of producer price inflation rates can be optimal: there is no inertia in the core inflation process. The second mechanism is necessary to support the first-best for any indexation rule other than full current indexation. For arbitrary core inflation processes, including partial and/or lagged indexation, the authorities can use the interest rate and/or the indirect tax rate to validate that core inflation process. Equations (75) and (52) characterise the sequences of indirect tax rates $\zeta_{t}, \zeta_{t+1}$ and/or nominal interest rates $i_{t+1, t}$ that support the optimum rate of producer price inflation. The optimal rate of producer price inflation, $\Pi_{t+1, t}=\Omega_{t+1, t}$ can, since $1+i_{t+1, t}=\frac{\beta^{-1} u^{\prime}\left(C_{t}\right)}{E_{t}\left[u^{\prime}\left(C_{t+1}\right) \tilde{\Pi}_{t, t+1}\right]}=$ $\frac{\beta^{-1} u^{\prime}\left(C_{t}\right)}{E_{t}\left[u^{\prime}\left(C_{t+1}\right) \frac{1+\zeta_{t}}{1+\zeta_{t+1}} \Omega_{t, t+1}\right]}$, be achieved with any constant value of the indirect tax rate, $\zeta_{t}=\zeta$, by varying the nominal interest rate on bonds, $i_{t+1, t}$, or with any constant value of the nominal interest rate on bonds $i_{t+1, t}=i$, by varying the indirect tax rate $\zeta_{t}$. I summarise this discussion in two corollaries:

Corollary 9 With full current indexation (or rational indexation with full contemporaneous information), any rate of producer price inflation can be optimal.

Corollary 10 With arbitrary indexation rules, the optimal rate of producer price inflation (which validates the core inflation rate) will not be constant if core inflation is not constant.

When the nominal interest rate on money is constrained to be constant, say $i_{t+1, t}^{M}=0$, the OQM rule requires that $i_{t+1, t}=0$, and the first-best can be achieved only with timevarying tax rates, unless $1=\frac{\beta^{-1} u^{\prime}\left(C_{t}\right)}{E_{t}\left[u^{\prime}\left(C_{t+1}\right) \Omega_{t, t+1}\right]}$ for all $t$.

Proposition 7 also holds if, rather unreasonably, the producer price indexation rule is a function of current, past and anticipated future rates of consumer price inflation only. 
Consider, e.g. the case where $\Omega_{t, t-1}=\tilde{\Pi}_{t, t-1}$. Equation (75) then implies that the optimal rates of producer and consumer price inflation are the same, that is, $\Pi_{t, t-1}=\tilde{\Pi}_{t, t-1}$, or $\zeta_{t}=\zeta_{t-1}$

With $i_{t+1, t}=i_{t+1, t}^{m}$ for all $t \geq 0$ we have $s_{t}^{j}=0$ and $\alpha=1$ for all $t \geq 0$ and for all $j \in[0,1]$. The price setting equilibrium condition (73) becomes

$$
\begin{gathered}
\left(\frac{\hat{p}_{t}(j)}{P_{t}}\right)^{-(1+\eta)}\left\{v^{\prime}\left(\ell_{t}^{j}\right)-\frac{\hat{p}_{t}(j)}{P_{t}} u^{\prime}\left(C_{t}\right)\right\} \\
+\sum_{k=t+1}^{\infty}(\omega \beta)^{k-t} E_{t}\left\{\frac{Y_{k}}{Y_{t}} \Pi_{t, k} \Omega_{k, t}\left(\frac{p_{k}(j)}{P_{k}}\right)^{-(1+\eta)}\left[v^{\prime}\left(\ell_{k}^{j}\right)-\frac{\hat{p}_{k}(j)}{P_{k}} u^{\prime}\left(C_{k}\right)\right]\right\}=0
\end{gathered}
$$

This will be satisfied by $v^{\prime}\left(\ell_{t}^{j}\right)-\frac{\hat{p}_{t}(j)}{P_{t}} u^{\prime}\left(C_{t}\right)=0$ for all $t \geq 0$ and for all $j \in[0,1]$. The OQM rule, the flexible commodity-specific production subsidy rule and the aggregate consumption tax rule together support the first-best equilibrium. The discount factors $(\omega \beta)^{k-t} E_{t} \frac{Y_{k}}{Y_{t}} \Pi_{t, k} \Omega_{k, t}\left(\frac{p_{k}(j)}{P_{k}}\right)^{-(1+\eta)}$ in equation (77) don't depend on the rate of inflation because of the indirect tax rule (75). Therefore, the equilibrium relative prices faced by consumers, $\frac{p_{t}(j)}{P_{t}}=\frac{\tilde{p}_{t}(j)}{\tilde{P}_{t}}$ which determine the consumption of the individual consumption goods $c_{t}^{j}(i)=\left(\frac{p_{t}(j)}{P_{t}}\right)^{-\eta} C_{t}$, given aggregate consumption, are also are independent of the rates of inflation of market prices and producer prices, regardless of the specification of the private price indexation functions.

Again, as with flexible prices and with price set one-period-in-advance, there is no unique optimal inflation rate associated with the first-best equilibrium if the nominal interest rate on money can be chosen freely. If the risk-free nominal interest rate on money is constrained to equal zero, the optimal consumer price inflation rate is that associated with a zero risk-free nominal interest rate on bonds. Unless there is full current indexation, the indirect tax rate will have to be used to achieve the optimal producer price inflation rate. 
Under the unrestricted optimal tax policy (74), the ratio of the after-production tax relative price received by the suppliers and the general price level at market prices satisfies:

$$
\int_{0}^{1}\left(\frac{p_{t}(j)}{P_{t}} \frac{1}{\left(1+\zeta_{t}\right)\left[1+\theta_{t}(j)\right]}\right)^{1-\eta} d j=\frac{\eta}{\eta-1}\left[\int_{0}^{1}\left(\frac{\hat{p}_{t}(j)}{P_{t}}\right)^{1-\eta} d j\right]^{\frac{1}{1-\eta}}
$$

Relative factor cost prices (and relative consumer prices) satisfy:

$$
\int_{0}^{1}\left(\frac{p_{t}(j)}{P_{t}}\right)^{1-\eta} d j=1=(1-\omega) \int_{0}^{1}\left(\frac{\hat{p}_{t}(j)}{P_{t}}\right)^{1-\eta} d j+\omega\left(\Pi_{t-1, t} \Omega_{t, t-1}\right)^{1-\eta} d j
$$

Given the optimal indirect tax rates policy given in (75), we have $\Pi_{t-1, t}=\Omega_{t, t-1}$ and

$$
\int_{0}^{1}\left(\frac{\hat{p}_{t}(j)}{P_{t}}\right)^{1-\eta} d j=1
$$

The mean of the cross-sectional distribution of relative prices set by free price setters is therefore the same as in the model with fully flexible prices.

\subsection{Optimal monetary policy with restricted fiscal policy rules}

I now consider optimal monetary policy, and the inflation rates associated with it, when fiscal policy cannot make use of information on current or past prices and endowments of individual suppliers. With such restricted fiscal policy rules the terms

$$
\Psi_{t}^{j} \equiv\left\{v^{\prime}\left(\ell_{k}^{j}\right)-u^{\prime}\left(C_{k}\right) \frac{p_{k}(j)}{P_{k}}\left(\frac{\eta-1}{\eta}\right)\left[\frac{1}{\left(1+\zeta_{t}\right)\left[1+\theta_{t}(j)\right]}-\alpha\left(s_{k}^{j}\right) \lambda_{k+1, k} \frac{C_{k}}{Y_{k}}\right]\right\}
$$

in equation (73) will not, in general, all be equal to zero. However, the equilibrium values of the real variables $\frac{p_{t}(j)}{P_{t}}, Y_{t}$ and $C_{t}$ will still be independent of the rates of inflation of market prices and producer prices, if simple fiscal rules can be found that ensure that both the discount factors $(\omega \beta)^{k-t} E_{t} \frac{Y_{k}}{Y_{t}} \Pi_{t, k} \Omega_{k, t}\left(\frac{p_{k}(j)}{P_{k}}\right)^{-(1+\eta)}$ and the $\Psi_{t}^{j}$ terms do not depend on either rate of inflation. I therefore consider first the details of a number of 
alternative indexation rules $\Omega_{k, t}$ and the arguments that support or detract from their plausibility, to determine whether the private price setting mechanism is itself producer price inflation-neutral (given constant production and consumption tax rates and constant nominal interest rates). Second, I check whether there are simple monetary and fiscal feedback rules that can neutralise any inflation non-neutralities in the private price setting mechanism.

In what follows, I establish the two following propositions and offer arguments in support of the view that the long-run equilibrium distribution of relative prices ought not to depend on the indexation rule even for constant values of the nominal and fiscal policy instruments.

Proposition 11 Regardless of the specification of the private indexation rule and the associated core inflation process, the authorities can always use either the indirect tax rate $\zeta_{t}$ or the nominal interest rate on bonds $i_{t+1, t}$ according to the simple rules given by (75) and (52), to eliminate any influence of the inflation rates on the real equilibrium. The uniform production subsidy given in (81) addresses efficiency losses due to monopoly power.

$$
\frac{1}{\left(1+\zeta_{t}\right)\left[1+\theta_{t}(j)\right]}=\frac{\eta}{\eta-1} \text { for all } j
$$

Optimal monetary policy is then again defined by the OQM rule (56), even if the fiscal policy rules are not flexible enough to support the first-best equilibrium.

Proposition 12 If the nominal interest rate on money is constrained to equal zero, the $O Q M$ rule requires $i_{t+1, t}=0$ and the optimal rate of producer price inflation $\Pi_{t, t-1}=$ $\Omega_{t, t-1}$ can, in general ${ }^{16}$ only be achieved using a time-varying indirect tax rate.

\footnotetext{
${ }^{16}$ Unless $1=\frac{\beta^{-1} u^{\prime}\left(C_{t}^{j}\right)}{E_{t}\left(u^{\prime}\left(C_{t+1}^{j}\right) \Omega_{t, t+1}\right)}$ for all $t$
} 
Under the fiscal rules (75) and (81),

$$
\begin{aligned}
\frac{p_{t}(j)}{P_{t}} \frac{1}{\left(1+\zeta_{t}\right)\left[1+\theta_{t}(j)\right]} & =\left(\frac{\eta}{\eta-1}\right) \frac{\hat{p}_{t}(j)}{P_{t}} \text { for free price setters } \\
& =\left(\frac{\eta}{\eta-1}\right) \frac{p_{t-1}(j)}{P_{t-1}} \text { for constrained price setters. }
\end{aligned}
$$

The fiscal rule (75) requires either that the constrained price setters use a full current indexation rule or that the authorities know the private sector's indexation rule $\Omega_{t, t-1}$ and are able to observe the variables included in the private sector's indexation rule. It is not necessary for the authorities to know, when they make the credible announcement (in period $t$ or earlier) of the tax rule (75) for period $t$, the values of all the variables (dated period $t$ or earlier) required to implement the period $t$ tax rule (that is, to send out the tax bill or the subsidy refund). It is only necessary that the authorities have this information in period $t$ or at some later time. Any payments from the private sector to the public sector (or vice versa) associated with the tax rule can be delayed until the required information (the realisations of the arguments in the rule) has become known to and verifiable by both parties involved in the tax or subsidy payment. As long as the present value of the payments does not depend on their timing (and they will not in the complete markets framework assumed here), the tax rules will have their intended effect even if the public sector were to observe aggregate variables later than the private sector - itself an unlikely scenario.

The ratio of the after-tax prices received by the producer to the general price level at market prices satisfies

$\frac{1}{\left(1+\zeta_{t}\right)}\left\{\int_{0}^{1}\left[\frac{p_{t}(j)}{P_{t}}\left(\frac{1}{1+\theta_{t}(j)}\right)\right]^{1-\eta} d j\right\}^{\frac{1}{1-\eta}}=\left(\frac{\eta}{\eta-1}\right)\left[(1-\omega) \int_{0}^{1}\left(\frac{\hat{p}_{t}(j)}{P_{t}}\right)^{1-\eta} d j+\omega\right]^{\frac{1}{1-\eta}}$

As before, relative factor cost prices (and relative consumer prices) satisfy: 


$$
1=(1-\omega) \int_{0}^{1}\left(\frac{\hat{p}_{t}(j)}{P_{t}}\right)^{1-\eta} d j+\omega\left(\Pi_{t-1, t} \Omega_{t, t-1}\right)^{1-\eta} d j
$$

Given the interest rate policy (if $i_{t, t-1}^{m}$ can be set freely) and/or the indirect tax rate policy given in (75), we have $\Pi_{t-1, t}=\Omega_{t, t-1}$ and

$$
1=\int_{0}^{1}\left(\frac{\hat{p}_{t}(j)}{P_{t}}\right)^{1-\eta} d j
$$

Equations (84) and (85) imply that

$$
\frac{1}{\left(1+\zeta_{t}\right)}\left\{\int_{0}^{1}\left[\frac{p_{t}(j)}{P_{t}}\left(\frac{1}{1+\theta_{t}(j)}\right)\right]^{1-\eta} d j\right\}^{\frac{1}{1-\eta}}=\frac{\eta}{\eta-1}
$$

From (84) it is clear that the tax rule cannot achieve full productive efficiency, since a fraction $\omega$ of producers is locked into last period's relative prices. However, the mean of the distribution of the relative prices set by free price setters is the same as in the unconstrained optimal equilibrium.

Under this optimal monetary policy and constrained fiscal policy combination, which can be implemented for with any indexation rule, the rate of inflation of the consumer price index is again indeterminate if the nominal interest rate on money can be chosen freely, because in that case the common risk-free nominal interest rates on bonds and money can be chosen freely.

\subsection{What indexation rule?}

The indexation rules $\Omega_{k, t}$ considered in what follows (and indeed the entire Calvo-class of price setting models) are $a d-h o c$, in the sense of not being derived as decision rules of purposefully acting agents starting from acceptable primitive assumptions (tastes, technology, endowments, information, contract enforcement institutions). Nevertheless, certain restrictions on permissible indexation rules can reasonably be imposed. One way to 'stress test' an ad-hoc indexation rule is to evaluate its performance in very simple, 
well-understood environments. As this paper investigates which inflation target (not necessarily constant) would be justifiable on utilitarian welfare-economic grounds, the indexation rule should be able to support more than one constant rate of inflation (indeed a non-trivial range of inflation rates) in a deterministic steady state. In this deterministic steady-state benchmark, all sources of uncertainty, other than the random allocation of suppliers to the free and constrained groups, are abstracted from and government spending $G_{t}$, individual endowments $e_{t}^{j}$, the consumption tax rate $\zeta_{t}$ and output tax rates $\theta_{t}^{j}$ are constant. ${ }^{17}$ There are complete markets for trading the risk associated with the random assignment of suppliers each period to the free and constrained groups.

\subsubsection{Woodford's indexation rule}

The indexation rule proposed by Woodford [41], which plays a central role in his argument for price stability (zero inflation) as the appropriate target for monetary policy, is given in equation (86). It applies to all suppliers that are not free to choose their optimal price $\hat{p}_{t}$ :

$$
p_{t}(j)=p_{t-1}(j)\left(\frac{P_{t-1}}{P_{t-2}}\right)^{\gamma}
$$

Woodford's model has a uniform production subsidy that eliminates inefficiencies due to the existence of monopoly power.

Using the notation of (66),

$$
\Omega_{t, t-1}=\left(\frac{P_{t-1}}{P_{t-2}}\right)^{\gamma}=\Pi_{t-1, t-2}^{\gamma}
$$

Under this indexation rule, the relative price of good $j$ for constrained suppliers evolves according to:

\footnotetext{
${ }^{17}$ This can easily be extended to steady states with a constant growth rate of the endowments and of GDP.
} 


$$
\frac{p_{t}(j)}{P_{t}}=\frac{p_{t-1}(j)}{P_{t-1}} \Pi_{t-1, t} \Pi_{t-1, t-2}^{\gamma}
$$

It is clear that this indexation rule (86), although it respects the 'homogeneity postulate', is a most unfortunate choice as the maintained hypothesis in an analysis of the welfare consequences of alternative inflation targets. Unless $\gamma=1$ or $\Pi_{t, t-1}=\Pi_{t-1, t-2}^{\gamma}$, the rule (86) introduces an arbitrary source of permanent inflation non-neutrality into the price setting behaviour of firms. When $\gamma=1, \frac{p_{t}(j)}{P_{t}}=\frac{p_{t-1}(j)}{P_{t-1}} \frac{\Pi_{t-1, t-2}}{\Pi_{t, t-1}}$ and the real equilibrium is invariant under alternative constant rates of inflation. When $0 \leq \gamma<1$, under any constant non-zero rate of inflation, ever-widening relative price distortions result, mechanically, from the application of the indexation rule (86).

Static relative prices have to satisfy the following relationship under Woodford's indexation rule:

$$
1-\omega\left(\Pi_{t-1, t} \Pi_{t-1, t-2}^{\gamma}\right)^{1-\eta}=(1-\omega) \int_{0}^{1}\left(\frac{\hat{p}_{t}(j)}{P_{t}}\right)^{1-\eta} d j .
$$

If $\Pi_{t, t-1}=\Pi_{t-1, t-2}^{\gamma}$ (actual inflation validates the core inflation process), which includes the zero inflation case $\left.\Pi_{t, t-1}=\Pi_{t-1, t-2}=1\right)$, then, under the Woodford indexation rule, the relative prices of those suppliers who are free to set their price in period $t$ satisfy $\int_{0}^{1}\left(\frac{\hat{p}_{t}(j)}{P_{t}}\right)^{1-\eta} d j=1$, which is a property shared by the equilibrium relative prices under full price flexibility. The prices set by the constrained price setters under the Woodford indexation rule would be $\frac{p_{t}(j)}{P_{t}}=\frac{p_{t-1}(j)}{P_{t-1}}$. However, if $\Pi_{t, t-1} \neq \Pi_{t-1, t-2}^{\gamma}$, a constant aggregate rate of factor cost inflation $\Pi$ would imply:

$$
\int_{0}^{1}\left(\frac{\hat{p}_{t}(j)}{P_{t}}\right)^{1-\eta} d j=\frac{1-\omega \Pi^{(\gamma-1)(1-\eta)}}{1-\omega}
$$

If the inflation rate is positive $(\Pi>1)$, then, since $\eta>1, \int_{0}^{1}\left(\frac{\hat{p}_{t}(j)}{P_{t}}\right)^{1-\eta} d j \lesseqgtr 1$ if $\gamma \gtreqless 1$. For instance, with a positive, constant rate of inflation and over-indexing $(\gamma>1)$, a constrained price setter's relative price will be rising over time for as long 
as he remains constrained. It will also be above-average cross-sectionally, forcing the relative prices of the free price setters to be below-average. If $\gamma<1$, the price setter would be systematically and persistently 'under-indexed', with his relative price declining exponentially to zero for as long as he is not free to set his price.

The indexation rule (86) therefore ought to be rejected because it implies unreasonable, indeed irrational, behaviour by constrained price setters in simple, well-understood environments in which over-indexing or under-indexing cannot be rationalised with an appeal to signal extraction, risk sharing or impaired learning ability. Even the mildest version of the Lucas critique would imply that the indexation rule in (86) would not survive (unless $\gamma=1$ ) if the firm that adopted it were operating in an environment with a constant but non-zero rate of inflation. If the firm stuck to the indexation rule, the firm would be unlikely to survive.

In an impartial analysis of inflation targeting, it is especially important that the dice not be loaded in favour of any particular rate of inflation, say zero, through the imposition of an arbitrary restriction on the indexation rule which (1) precludes the existence of a deterministic steady state with any non-zero rate of inflation, and (2) implies, when there is a constant but non-zero rate of producer price inflation, highly implausible configurations of relative prices over time and cross-sectionally, and a persistent (indeed permanent) inability to learn by private price setters.

Of course, even when $\gamma \neq 1$, the implementation of simple rules for the nominal interest rate and/or the indirect tax rate (75) will make the price setting mechanism inflation-neutral. Under (75), it will always be the case that producer price inflation satisfies $\Pi_{t, t-1}=\Pi_{t-1, t-2}^{\gamma}$. Consumer price inflation is then given by $\tilde{\Pi}_{t, t-1} \equiv \frac{1+\zeta_{t}}{1+\zeta_{t-1}} \Pi_{t-1, t-2}^{\gamma}$. Thus, regardless of whether Woodford's indexation rule is dropped and replaced by something more sensible or kept and neutralised or validated by a simple indirect tax rule or nominal interest rate rule, price stability (of either the consumer price level or the producer price level) is neither necessary nor sufficient for monetary policy to be optimal. When the nominal interest rate on money is constrained to be zero, consumer price 
stability is inconsistent with optimal monetary policy, except in a cashless economy.

\subsubsection{Ad-hoc indexation rules that permit steady states with non-zero infla- tion rates}

Consider a slightly generalised of Woodford's proposed indexation rule given in equation $(89):{ }^{18}$

$$
p_{t}(j)=p_{t-1}(j)\left(\frac{P_{t}}{P_{t-1}}\right)^{\delta}\left(\frac{P_{t-1}}{P_{t-2}}\right)^{\gamma}, \quad 0 \leq \delta, \gamma \leq 1
$$

or

$$
\frac{p_{t}(j)}{P_{t}}=\Pi_{t, t-1}^{\delta-1} \Pi_{t-1, t-2}^{\gamma}
$$

In terms of our generic indexation rule (66) this implies:

$$
\Omega_{t, t-1}=\Pi_{t, t-1}^{\delta} \Pi_{t-1, t-2}^{\gamma}
$$

This formulation includes as special cases both Calvo's original model, where a constant nominal price is maintained by the constrained suppliers $(\delta=\gamma=0)$ and Woodford's formulation $(\delta=0)$. As I am only interested in economic systems that can support, in the deterministic special case, steady states with more than one constant rate of inflation, I will concentrate on the case where $\delta=1-\gamma$.

The indexation rule given in (89) is also subject to the Lucas critique. Unless either the core inflation process is validated $\left(\Pi_{t, t-1}=\left(\Pi_{t-1, t-2}\right)^{\frac{\gamma}{1-\delta}}\right)$, or $\delta=1$ and $\gamma=0$, the relative price of good $j, \quad p_{t}(j) / P_{t}$ will be subject to inefficient cross-sectional and timeseries variation. Any constant aggregate rate of inflation would keep the relative price of good $j$ constant. For instance, when $\delta=1-\gamma$, equation (89) can be written as $\frac{\pi_{t, t-1}(j)}{\Pi_{t, t-1}}=$ $\left(\frac{\Pi_{t-1, t-2}}{\Pi_{t, t-1}}\right)^{\gamma}$. This implies a systematic and persistent decline in the relative price of

\footnotetext{
${ }^{18}$ This can easily be generalised to an autoregressive-moving average process like $A(L) \pi_{t, t-1}=$ $B(L) \Pi_{t, t-1}$ where $A(L)$ and $B(L)$ are polynominal distributed lag functions with $A(1)^{-1} B(1)=1$.
} 
constrained suppliers if the economy-wide rate of inflation were rising systematically and persistently, if $\gamma>0$. The indexation rule (89) therefore only makes sense if there is no significant trend (positive or negative) in the rate of inflation.

A possible attractive generalisation of (89) would be along the lines of John Flemming's 'gearing hypothesis' (see Flemming [24]). Flemming's hypothesis, proposed as a theory of inflation expectation formation rather than as a theory of indexation rules, held that as long as the price level was stationary, a simple, ad-hoc forecasting rule (indexation rule for our purposes) relating the predicted price level to past realisations of the price level (subject to a homogeneity constraint) would be adopted. For indexation rules that only use aggregate information from the current and most recent past period, we would, when the aggregate price level is stationary, have a rule like:

$$
p_{t}(j)=P_{t}^{1-\gamma} P_{t-1}^{\gamma} \text {. }
$$

If a trend were to appear in the price level but not in the rate of inflation (if the price level were to become non-stationary but the rate of inflation remained stationary), forecasts would 'shift up a gear' (because learning takes place) and a forecasting rule relating the forecast of the inflation rate to the past behaviour of the inflation rate would be adopted. The indexation rule (89) is an example. If the inflation rate became non-stationary but the change in the rate of inflation remained stationary, the forecasting rule would again shift up a gear. The indexation rule would become:

$$
\frac{\pi_{t, t-1}(j)}{\pi_{t-1, t-2}(j)}=\left(\frac{\Pi_{t, t-1}}{\Pi_{t-1, t-2}}\right)^{1-\gamma}\left(\frac{\Pi_{t-1, t-2}}{\Pi_{t-2, t-3}}\right)^{\gamma}
$$

A statistical description of Flemming's gearing hypothesis as applied to indexation rules would be that the economy-wide inflation rate and the supplier's inflation rate generated by the indexation rule are 'co-integrated'. The indexation rule (or the inflation expectation formation process), without meeting the full-fledged model-consistency requirement of the Lucas critique, does meet the less demanding, but possibly more relevant, 
requirement that it should not be 'off' by an order of integration or more.

With constant indirect tax rates, the indexation rule (89) makes the real equilibrium invariant to any constant inflation rate of producer prices if $\delta=1-\gamma$. It makes the real equilibrium invariant to any rate of inflation, constant or not, if in addition $\delta=1$ the case of full current indexation. Regardless of the values of $\gamma$ and $\delta$, implementation of the fiscal rule (75) and/or appropriate use of the nominal interest rate will make the real equilibrium invariant under alternative inflation rates, by validating core inflation: $\Pi_{t, t-1}=\Pi_{t-1, t-2}^{\frac{\gamma}{1-\delta}}$.

\subsubsection{Full current indexation}

As noted in Woodford [41], pp. 214-215, all inflation inertia vanishes (with constant values of all policy instruments) in Calvo-type models with full current indexation. This corresponds to the case $\delta=1$ and $\gamma=0$ in equation (89).

With zero production and consumption tax rates, there remain three distortions when monetary policy is exogenous: (1) monopoly power; (2) insufficient relative price flexibility, which prevents constrained suppliers from responding with their prices to idiosyncratic shocks to their endowment; (3) a non-zero opportunity cost of holding money balances (when $i>i^{m}$ ). Since the real equilibrium under full current indexation is independent of the rate of inflation, optimal monetary can be dedicated to implementing the OQM rule.

\subsubsection{Full current indexation as relative price contracting}

The fact that, in period $t$, the price instrument of supplier $j$ is the price of good $j$ in terms of period $t$ money, $p_{t}(j)$, does not mean that supplier $j$ is unaware that it is the relative price of good $j, p_{t}(j) / P_{t}$, rather than its nominal price, that determines the demand for his product . Nominal price setting, and the nominal inertia that may result from it are not money illusion. Since it is the relative price of good $j$ that matters to supplier $j$ , a price indexation rule for supplier $j$ could be plausibly argued to be a relative price 
contracting rule, that is, a rule that is motivated by a desire to achieve an acceptable or reasonable value for this relative price during the periods that supplier $j$ is not free to set the relative price of his product. As a simple example consider the relative price contracting rule given in (90), which mimics the nominal price indexation rule in (89):

$$
\frac{p_{t}(j)}{P_{t}}=\frac{p_{t-1}(j)}{P_{t-1}}\left(\frac{p_{t}(j) / P_{t}}{p_{t-1}(j) / P_{t-1}}\right)^{\bar{\delta}}\left(\frac{p_{t-1}(j) / P_{t-1}}{p_{t-2}(j) / P_{t-2}}\right)^{\bar{\gamma}} .
$$

It can be rewritten as a nominal price indexation rule:

$$
p_{t}(j)=p_{t-1}(j) \Omega_{t, t-1}(j)
$$

where

$$
=\Pi_{t, t-1}\left(\frac{\pi_{t, t-1}(j)}{\Pi_{t, t-1}}\right)^{\bar{\delta}}\left(\frac{\pi_{t-1, t-2}(j)}{\Pi_{t-1, t-2}}\right)^{\bar{\gamma}} .
$$

The full current indexation rule for the nominal producer price is the special case of this relative price contracting rule (90) when $\bar{\delta}=\bar{\gamma}=0$. It can be contrasted with Calvo's original specification in which a nominal price freely set in period $t$ has to be kept constant until the next random opportunity for changing that price $(\delta=\gamma=0$ in equation (89)) - a model of staggered overlapping nominal price setting similar in spirit and in many of its key properties to Taylor's model of staggered, overlapping two-period nominal wage contracts (Taylor [40]).

The natural interpretation of Calvo's nominal price setting model with full indexation $(\delta=1, \gamma=0$ in equation (89)) is that household $j$, when it is among the randomly selected households whose price contracts can be altered in period $t$, sets a constant relative price for good $j$ in terms of the composite consumption good, to remain in effect until the next random opportunity for changing this relative price comes along. This relative price setting model is in the spirit of Buiter and Jewitt [10], and Buiter and Miller [11]. Buiter and Jewitt [10] extended Taylor's [40] analysis of staggered 
overlapping nominal wage contracts (motivated with a concern by workers for relative money wages) by developing and analysing a model of staggered overlapping real wage contracts (motivated with a concern by workers for relative real wages). Buiter and Miller [11] developed a continuous time version of a Calvo-type model in which new contracts fix (until the next random opportunity for re-contracting) not the nominal value of the contract price but the proportional rate of change of the nominal contract price.

An even closer approximation to the key properties of the Buiter and Jewitt and Buiter and Miller models would be to take the $\bar{\delta}=\bar{\gamma}=0$ version of equation (90) and to lag the relative price benchmark one period: $\frac{p_{t}(j)}{P_{t-1}}=\frac{p_{t-1}(j)}{P_{t-2}}$. This can be written as a nominal price indexation rule with full but one-period-lagged indexation: $p_{t}(j)=p_{t-1}(j) \Pi_{t-1, t-2}$, which is also the special case of (89) with $\delta=0$ and $\gamma=1$. The resulting model, like the Buiter-Miller model and the 2-period version of the Buiter-Jewitt model, is in all relevant respects the same as the Calvo model with full one-period lagged indexation considered by Christiano et. al.[18], Smets and Wouters [37] and Woodford [41]. ${ }^{19}$. They generate inflation inertia and not just price level inertia when the commodity tax rates are constant. ${ }^{20}$ The real equilibrium of these models is invariant under alternative constant rates of inflation.

The full current indexation rule assumes that the period $t$ constrained price setters index fully to the actual realisation of the period $t$ aggregate price level. A slightly

\footnotetext{
${ }^{19}$ See also Buiter [5] for an open economy version of the Buiter-Miller inflation inertia model and Buiter [6] for an analysis of optimal disinflation policies and the case for gradualism in the Buiter-Miller Model.

${ }^{20}$ As pointed out in Buiter and Jewitt [10], the price level equation generated by the N-period staggered overlapping relative money wage contract is an $\operatorname{ARIMA}(\mathrm{N}-1, \mathrm{~N}-1)$ process, while the price level generated by the $\mathrm{N}$-period staggered, overlapping relative real wage process is an ARIMA $(2 \mathrm{~N}-2,2 \mathrm{~N}-2)$ process. When $\mathrm{N}=2$, this means that the relative money wage model has price level inertia (an ARIMA $(1,1)$ process) but not inflation inertia, while the relative real wage model has inflation persistence (an ARIMA $(2,2)$ process. Of course, the relative money wage process with $\mathrm{N}=3$ also generates an ARIMA $(2,2)$ process for the price level. Unless one knows $\mathrm{N}$ a-priori, there is an observationally equivalent relative money wage model for every relative wage model. For some reason, the empirical literature seems to be stuck on the N-2 case. With yearly contracts this may make sense if the unit period of analysis and measurement is a year. However, if the true length of the typical (US) wage contract is 2 years, but contracts are negotiated every quarter and the distribution of contract renewals is uniform over the year, then, taking the quarter to be the unit period, $\mathrm{N}=8$. The relative money wage model would imply an $\operatorname{ARIMA}(7,7)$ for the general price level (using quarterly data) and the relative real wage money an ARIMA(12,12) process. Plenty of inflation persistence therefore from both models and, I would think, a difficult task of discriminating between them using, say, 160 or 200 quarterly observations.
} 
weaker variant assumes indexation to the expected value of the current aggregate price level:

$$
\Omega_{t, t-1}=E_{t-1} \Pi_{t, t-1}
$$

With (91), alternative deterministic inflation sequences would be associated with identical values of the model's real equilibrium variables. Unanticipated inflation would have real effects, unless the authorities validate the core inflation process by using their interest rate and/or indirect tax instruments to achieve $\Pi_{t, t-1}=E_{t-1} \Pi_{t, t-1}$.

\section{Conclusion}

I have analysed the inflation rate associated with optimal monetary policy and either optimal or constrained but supportive tax policy in a suite of models that are in the modern mainstream of dynamic stochastic (mostly) optimising macroeconomic general equilibrium tradition. The implications of the analysis are clear. In all models (flexible prices, one-period-ahead nominal price setting and Calvo-style staggered overlapping price setting with any kind of indexation rule for the constrained price setters), the optimal monetary policy is given by the 'Optimal Quantity of Money' rule, that the financial opportunity cost of holding money must be equal to zero. If the nominal interest rate on money can be set freely by the authorities, there is no unique consumer price inflation rate associated with the optimal monetary rule. By varying the risk-free nominal interest rate on bonds (while keeping it equal to the risk-free nominal interest rate on money), any sequence of consumer price inflation rates, positive or negative, can be supported by an optimal monetary policy. With an exogenously given zero nominal interest rate on money, the consumer price inflation rate associated with the optimal monetary policy is the consumer price inflation rate supported by a zero risk-free nominal interest rate on bonds. In a deterministic steady state that would be a negative consumer price inflation rate equal to minus the rate of time preference. 
The most striking result is that the OQM rule characterises optimal monetary policy (except, of course, in a cashless economy) when there are Calvo-style price contracts, regardless of the indexation rule adopted by constrained price setters. It holds, for instance, for the lagged partial indexation rule that plays such a key role in Woodford's case for price stability as the target of monetary policy. When the nominal interest rate on money can be set freely, the OQM rule is optimal even if the indirect tax rate is kept constant. For the OQM rule to be optimal when the nominal interest rate on money is constrained to be zero, one either needs well-posed private indexation rules (such full current indexation with and either complete or partial information), or the adoption by the authorities of a simple feedback rule for the indirect tax rate. By validating the core inflation process, the real equilibrium becomes inflation-neutral even if the private price indexation rules are ill-posed and arbitrary. Optimal producer price inflation will not be constant unless core inflation is constant.

Woodford ([41]) analysed models similar to those used in this paper. After considering the Calvo price setting model with a number of indexation rules, he reaches to following conclusion, which is starkly different from that of this paper: "Thus aggregate price stability is a sufficient condition for the absence of price dispersion in the present simple framework" (p. 405). "At the same time, in most cases, it is also a necessary condition" (p. 405); and: "...in a model with staggered pricing and full indexation to a lagged price index, price stability is not necessary for the absence of price dispersion; it is simply necessary that the inflation rate be constant over time. But again this is a highly special case. If the indexation parameter $\gamma$ takes any value other than one, only zero inflation is consistent with an absence of price dispersion". (p. 406).

To be correct, the last part of the last sentence of this quote should be "..., zero inflation is the only constant rate of inflation consistent with an absence of suboptimal price dispersion".

Woodford recognises further on (in Chapter 6 of Woodford [41]), that his analysis of the relationship between relative price dispersion and the aggregate inflation rate only 
implies that zero inflation should be the objective of monetary policy if there are no shoe-leather and Austrian (cash-good vs. credit good) distortions in the economy. Even if monetary distortions are absent, the results of this paper are different from those of Woodford. There are two reasons for this, each of which is sufficient to invalidate the proposition that, in the class of models under consideration, price stability is necessary or sufficient for optimality. First, the lagged partial indexation rule for which Woodford establishes that zero inflation is necessary for optimality is implausible and inappropriate for an analysis of how the economy would perform under alternative constant inflation targets. With partial indexation and constant indirect taxes, there can be no constant inflation rate other than zero in a deterministic steady state. The relative price anomalies, cross-sectionally and over time, that result from this arbitrary indexation rule under any non-zero constant rate of inflation, would lead even the most cerebrally challenged price setter to abandon the Woodford indexation function as he learned about the relationship between his indexation rule and the behaviour of his relative price.

The simplest plausible alternative to the Calvo pricing model with Woodford's indexation function is the natural modification of the pure Calvo model that assumes that free price setters choose not a fixed nominal price but a fixed relative price until their next random opportunity for setting the relative price freely. Individual money prices then adjust in line with the aggregate producer price level to maintain this relative price until the next free pricing opportunity. In this model, there is full current indexation and the real equilibrium is independent of the rate of inflation. Reasonable alternative relative price indexation rules result in the real equilibrium being invariant under alternative fully anticipated inflation sequences or under alternative constant inflation rates.

The second reason the results of this paper differ from those of Woodford hold for any price indexation rule, including Woodford's. I assume that the authorities are capable of implementing a very simple nominal interest rate rule and/or a very simple feedback rule for the indirect tax rate. Under this rule, the producer price core inflation process is validated by policy and any inflation non-neutralities in the private price setting 
mechanism are neutralised. The OQM rule is optimal under any price indexation rule if the nominal interest rate and/or the indirect tax rate can be used responsively in this way. Woodford implicitly assumes either that interest rate-setting and tax-setting authorities are completely unresponsive to aggregate information that is readily available or that they can only target a constant rate of inflation.

This paper does not argue that there are no valid arguments in favour of price stability (defined as zero inflation for some appropriate aggregate price or cost-of-living index) as an objective, or even the overriding objective, of monetary policy. All it says is that in the canonical suite of models considered in the paper, price stability is not a property of optimal monetary policy if either the private price setters are capable of learning or the tax authorities are capable of implementing a simple feedback rule for the nominal interest rate and/or the indirect tax rate.

The result of this paper that optimal monetary policy should implement the Optimal Quantity of Money rule is not robust to two important extensions. The first is the introduction of constraints on the ability of the authorities to impose lump-sum taxes or make lump-sum transfers. With such constraints, seigniorage revenues, that is, the real resources appropriated by the authorities through the issuance of base money, can become a valuable source of revenue for the authorities. When the interest rate on money is zero, this may raise the inflation rate associated with optimal monetary policy. ${ }^{21}$

The second extension is menu costs, that is, the explicit consideration of the real resource costs associated with changing prices or renegotiating price contracts, as in the papers of Caplin and Spulber [16] and Caplin and Leahy [17]. Such menu costs should be interpreted broadly to include the time, effort and inconvenience of measuring, computing and calculating with an inconvenient yardstick whose length varies from period to period.

\footnotetext{
${ }^{21}$ For seigniorage (or the anticipated inflation tax on base money) to matter, we also have to impose constraints on the ability of the authorities to raise distortionary tax rates. Without this, all the government's current and future revenue needs could be satisfied in the initial period through what amounts to a capital levy. If any non-monetary nominal debt is outstanding, it may also be necessary to impose a limit on the government's ability to inflict capital losses on the private owners of nominal public debt through an unanticipated jump in the initial price level.
} 
The implications of menu costs for the optimal rate of inflation depend crucially on the details of how menu costs are modeled. It makes a difference whether a real sunk cost is incurred every time a nominal price is changed, or only when a new contract (which may involve indexation clauses) is negotiated. Nominal price changes that are the result of the mechanical implementation of an invariant indexation rule may have lower menu costs than those that are the result of bargaining between buyers and sellers or the outcome of an auction. If menu costs are assumed to be particularly important for the goods and services that make up the cost-of-living index, this would drive the optimal inflation rate of the cost of living index closer to zero. If, as seems more plausible, menu costs are especially important for money wages (negotiating and bargaining over wages, whether bilaterally or through organised labour unions and/or employers' associations is costly and time-consuming), a zero rate of money wage inflation would be a natural focal point of monetary policy. With positive labour productivity growth, zero wage inflation would imply a negative rate of inflation for the cost of living, consumer and producer price indices.

Finally, a reflection on the limitations - the tameness - of the standard suite of models considered in this paper and on their usefulness as a guide for monetary and fiscal policy in times of recession and macroeconomic instability. All the distortions in the economy are 'Harberger Triangles' rather than 'Okun Gap' distortions. Monopoly power and the inefficiencies associated with a non-zero financial opportunity cost of holding money are standard micro fare. The distortions caused by nominal price rigidities are a sub-optimal degree of relative price dispersion; formal or informal price indexation rules that do not suffer from persistent, indeed permanent, inflation non-neutrality make these distortions disappear, perhaps gradually, if learning takes place. If the private price setting mechanism suffers from persistent inflation non-neutralities, minor tinkering with the interest rate and/or the aggregate indirect tax rate will make these distortions disappear. It all looks like rather small beer. Does any central banker lie awake worrying about a suboptimal degree of relative price dispersion among monopolistically competitive industries? 
Should they? It is hard to discern anything that resembles a failure of effective demand or hints at crises. This is hardly the stuff of Great Depressions, severe or even regular recessions. Is it time to stop hanging ever more small rigidities, frictions, ad-hoc behavioural regularities and other New-Keynesian ornaments on the old dynamic stochastic general equilibrium Christmas tree, and to try for something radically new?

\section{References}

[1] Archer, D. J. [2000], "Inflation Targeting in New Zealand", presentation to a seminar on inflation targeting, held at the International Monetary Fund, Washington, DC, March 20-21, 2000.

[2] Bailey, Martin J. [1956], "The Welfare Costs of Inflationary Finance," Journal of Political Economy, vol. 64, no. 2 , April, pp. 93-110.

[3] Bernanke, B. S. and M. Woodford, eds. [2004], Inflation Targeting, University of Chicago Press, Chicago, forthcoming.

[4] Brock, William A. [1974], "Money and Growth: The Case of Long Run Perfect Foresight", International Economic Review, 15(3), October, pp. 750-777.

[5] Buiter, W. H. [1985], "International Monetary Policy to Promote Economic Recovery," in Monetary Conditions for Economic Recovery, C. van Ewijk and J.J. Klant (eds.), Financial and Monetary Policy Studies 11, Martinus Nijhoff Publishers, Dordrecht, 1985.

[6] Buiter, W. H. [1986], "Policy Evaluation and Design for Continuous Time Linear Rational Expectations Models: Some Recent Developments," in Prices, Competition and Equilibrium, M. H. Peston and R. E. Quandt (eds.), 1986, Barnes \& Noble Books, 84-108.

[7] Buiter, W. H. [2003], "Helicopter Money: Irredeemable Fiat Money and the Liquidity Trap", NBER Working Paper No. 10163, December 2003.

[8] Buiter, W. H. [2004], "Reply to Davies", mimeo, European Bank for Reconstruction and Development, June.

[9] Buiter, W. H. [2005], " A Small Corner of Intertemporal Public Finance. New Developments in Monetary Economics: two ghosts, two eccentricities, a fallacy, a mirage and a mythos", Royal Economic Society 2004 Hahn Lecture, given on 6 April 2004, at the Royal Economic Society Annual Conference, Swansea, UK. forthcoming The Economic Journal, Conference Papers, 2005.

[10] Buiter, W. H. and I. [1981], "Staggered Wage Setting with Real Wage Relativities: Variations on a Theme of Taylor", Manchester School, 49, September, pp. 211-28., 
reprinted in W. H. Buiter, Macroeconomic Theory and Stabilisation Policy, Michigan University Press, Ann Arbour, Michigan, pp. 183-199.

[11] Buiter, W. H. and M. H. Miller [1985], "Costs and benefits of an anti-inflationary policy: questions and issues", in A. Argy and J. Nevile eds. Inflation and Unemployment: Theory, Experience and Policy Making, London, George Allen \& Unwin, pp. 11-38, reprinted in W. H. Buiter, Macroeconomic Theory and Stabilisation Policy, Michigan University Press, Ann Arbour, Michigan, pp. 200-227.

[12] Buiter, W. H. and N. Panigirtzoglou [2001], "Liquidity Traps: How to Avoid Them and How to Escape Them", in Reflections on Economics and Econometrics, Essays in Honour of Martin Fase, edited by Wim F.V. Vanthoor and Joke Mooij, 2001, pp. 13-58, De Nederlandsche Bank NV, Amsterdam.

[13] Buiter, W. H. and N. Panigirtzoglou [2003], "Overcoming the Zero Bound on Nominal Interest Rates with Negative Interest on Currency: Gesell's Solution", Economic Journal, 113, October 2003, pp. 723-746.

[14] Buiter, Willem H. and A. C. Sibert [2004], "Deflationary Bubbles", NBER Working Paper No. 10642, July.

[15] Calvo, Guillermo [1983], "Staggered Contracts in a Utility-Maximizing Framework," Journal of Monetary Economics, September.

[16] Caplin, A. and D. Spulber [1987], "Menu Costs and the Neutrality of Money", Quarterly Journal of Economics, 102, pp. 703-725.

[17] Caplin, A. and J. Leahy, [1991], "State Dependent Pricing and the Dynamics of Money and Output," Quarterly Journal of Economics, 106, pp. 683-708.

[18] Christiano, L. J., M. Eichenbaum and C. Evans, "Nominal Rigidities and the Dynamic Effects of a Shock to Monetary Policy", NBER Working Paper, No. 8403 (July 2001).

[19] Costa C. and P. deGrauwe [2001], "Monetary Policy in a Cashless Society", CEPR Discussion Paper, No. 2696, February.

[20] Davies, Stephen [2004], "Comment on Buiter and Panigirtzoglou", mimeo, Research Institute for Economics and Business Administration, Kobe University, May.

[21] Dixit, A K. and J. Stiglitz [1977], "Monopolistic Competition and Optimum Product Diversity", American Economic Review, 67, pp. 297-308.

[22] Einaudi, Luigi [1953], "The Theory of Imaginary Money from Charlemagne to the French Revolution," in F. C. Lane and J. C. Riemersma, eds. Enterprise and Secular Change (George Allen and Unwin, New York, pp. 229 -61.

[23] Eisler, Robert [1932], Stable Money: the remedy for the economic world crisis: a programme of financial reconstruction for the international conference 1933; with a preface by Vincent C. Vickers. London: The Search Publishing Co. 
[24] Flemming, J. [1976], Inflation. New York: Oxford University Press.

[25] Freedman, C. [2000], "Monetary Policy Implementation: Past, Present and Future - Will Electronic Money Lead to the Eventual Demise of Central Banking?", International Finance, 3, pp. 211-227.

[26] Friedman, B. M. [1999], "The Future of Monetary Policy: the Central Bank as an Army with Only a Signal Corps?", International Finance, 2, pp. 321-338.

[27] Friedman, M. [1969], "The Optimum Quantity of Money", in Milton Friedman, The Optimum Quantity of Money and Other Essays, Chapter 1, pp.1-50, Adline Publishing Company, Chicago.

[28] Gesell, Silvio [1916], Die Natuerliche Wirtschaftsordnung, Rudolf Zitzman Verlag (in English: The Natural Economic Order, Peter Owen Ltd, London, 1958).

[29] Goodfriend, M. [2000], "Overcoming the Zero Bound on Interest Rate Policy", Journal of Money, Credit and Banking, Vol. 32, No. 4, Pt. 2, November, 1007-1035.

[30] Goodhart, C. A. E. [2000], "Can Central Banking Survive the IT Revolution?", International Finance, 3, pp. 189-209.

[31] Hall, R. E. [2002], "Controlling the Price Level", Contributions to Macroeconomics: Vol. 2: No. 1, Article 5, http://www/bepress.com/bejm/contributions/vol2/iss1.art5

[32] King, Mervyn [2002], "The inflation target ten years on", Bank of England Quarterly Bulletin, Vol. 42, No. 4, Winter, pp.459-474.

[33] Lucas, R. E. [1980], "Equilibrium in a pure currency economy", Economic Inquiry, 18(2), pp. 203-220.

[34] Lucas, R. E. [1982], "Interest Rates and Currency Prices in a Two-Country World", Journal of Monetary Economics, 10(3), pp. 335-359.

[35] McCallum, B. T. and M. S. Goodfriend[1986], "Money: Theoretical Analysis of the Demand for Money," in The New Palgrave: A Dictionary of Economic Theory and Doctrine. London: The Macmillan Press, 1987. Also in Federal Reserve Bank of Richmond, Economic Review, 74 (January/February 1988), 16-24.

[36] Mishkin, F., B. Bernanke, T. Laubach and A. Posen [1999], Inflation Targeting: Lessons from the International Experience (Princeton University Press: Princeton.

[37] Smets, F. and R. Wouters [2003], "Shocks and Frictions in US Business Cycles: A Bayesian DSGE Approach", European Central Bank mimeo, 9 May.

[38] Svensson, L. E. O. [2001], "Price Stability as a Target for Monetary Policy: Defining and Maintaining Price Stability," in Deutsche Bundesbank, ed., The Monetary Transmission Process: Recent Developments and Lessons for Europe, Palgrave, New York, 60-102. 
[39] Svensson, L. E. O. and M. Woodford[2004], "Implementing Optimal Policy through Inflation-Forecast Targeting," in Bernanke, B. S., and M. Woodford, eds., Inflation Targeting, University of Chicago Press, Chicago, forthcoming.

[40] Taylor, J. B. [1980], "Aggregate Dynamics and Staggered Contracts", Journal of Political Economy, 88, pp. 1-23.

[41] Woodford, Michael (2003), Interest and Prices; Foundations of a Theory of Monetary Policy, Princeton University Press, Princeton and Oxford. 